\title{
CONSPIRACY LAW's THREAT TO FREE SPEECH*
}

\author{
Steven R. Morrison ${ }^{\dagger}$
}

\begin{abstract}
Conspiracy law has been the consistent subject of controversy, but most commentators do not consider its negative effect on freedom of speech. When they do, their concerns focus only on the use of speech as the crime's actus reus. The use of speech as evidence to prove this actus reus is as important and raises conceptually related issues, so current scholarship tells only half of the story.
\end{abstract}

This Article addresses the use of speech as the actus reus of conspiracy and evidence thereof. It sets forth what I call the All-Purpose Speech Model. I argue that this Model accurately describes the use of speech in conspiracy cases, and thereby reveals threats to free speech not recognized by past approaches to the subject.

Current scholarship's unipolar approach has led some commentators to conclude that conspiracy law poses no threat to freedom of speech. Contrary to the necessary assumptions underlying this conclusion, the All-Purpose Speech Model discounts the operational distinction among agreement, overt act, mens rea, and evidence thereof. It reveals that these elements and evidence in support of them collapse together, becoming homogenized. The result is that speech used as evidence becomes the crime of conspiracy itself. This raises serious concerns for free speech.

This Article first provides a factual context by discussing conspiracy issues in terrorism, communism, and narcotics cases. It then sets forth the All-Purpose Speech Model by exploring the intersection between conspiracy law and free speech. Next, it uses Kent Greenawalt's tripartite structure of speech and the category of speech integral to criminal conduct to establish a new fourpart typology that illustrates the threat to free speech posed by conspiracy law. Finally, it applies this typology to the extant system of speech protection, which includes the familiar concepts of highvalue speech, low-value speech, and speech thought to be entirely outside of the First Amendment's protection.

This Article addresses only conspiracy's threat to principles of freedom of speech. A different, and equally important, inquiry concerns its potential violation of the First Amendment. Recognizing the novelty of its argument and the political, evidentiary, and conceptual challenges of placing conspiracy charge-related speech under First Amendment protection, I reserve that inquiry for later

* Copyright 2011, Steven R. Morrison.

$\dagger$ Assistant Professor of Law, University of North Dakota School of Law. I would like to thank Larry Alexander, R. Michael Cassidy, Roger S. Clark, Ronald K.L. Collins, Ellen Podgor, Aziz Huq, Andrew March, Paul Marcus, Peter S. Margulies, Lawrence Rosenthal, Robin R. Runge, and SpearIt for their invaluable comments on earlier drafts. I am grateful also to the International Centre for Criminal Law Reform and Criminal Justice Policy, at whose 2011 annual conference I presented an early version of this Article, and also to Loyola University Chicago School of Law, at whose 2011 constitutional law colloquium I presented this work. Finally, I am grateful to the University of North Dakota School of Law and Dean Kathryn R.L. Rand for their support. A law school summer research grant made this Article possible. All errors are my own. 
work, so that it may be given the attention it deserves. Nonetheless, I conclude with a tentative

foray into Brandenburg-related constitutional questions posed by conspiracy law.

\section{TABLE OF CONTENTS}

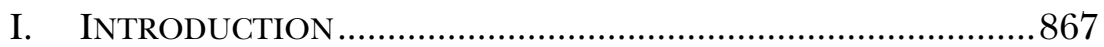

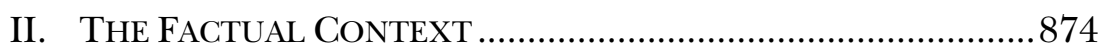

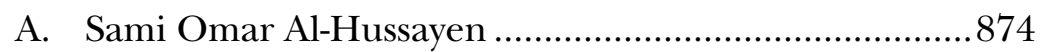

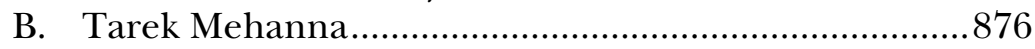

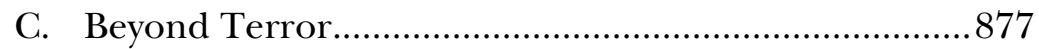

D. Communism, Hip-Hop, and Jihad...............................878

E. World-Wide Communism and the Global Jihad

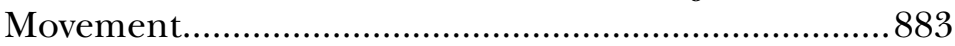

F. Law Enforcement Responses.....................................886

III. THE INTERSECTION OF SPEECH AND CONSPIRACY ..................889

A. When the All-Purpose Speech Model Presents No

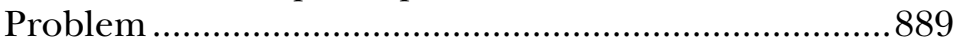

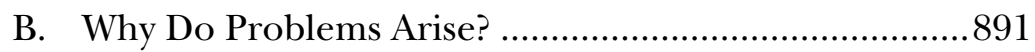

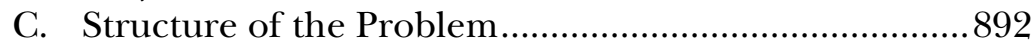

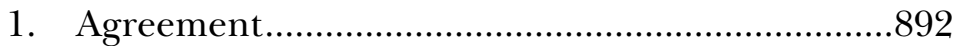

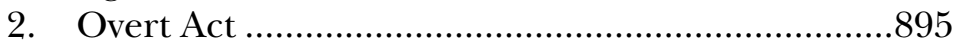

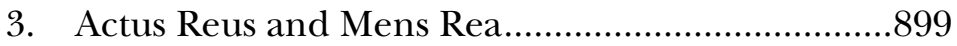

4. Actus Reus and Evidence Thereof ..........................900

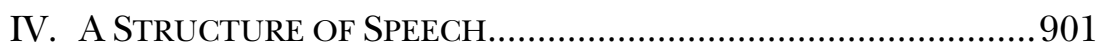

A. Pre-Existing Structures ..................................................901

1. Speech Integral to Criminal Conduct ....................901

2. What is "Integral" Speech? ......................................903

3. Greenawalt's Theory of Speech Acts......................906

B. Problems With Greenawalt's Tripartite Structure........908

C. Distilling Greenawalt's Structure .................................910

1. Combining Integral Speech and the Aspirational-Operational Structure

V. OF CONSPIRACIES AND THREATS TO PRINCIPLES OF FREE SPEECH.

VI. CONClusion. 


\section{INTRODUCTION}

Since its advent in the thirteenth and fourteenth centuries, criminal conspiracy law has been, at least in hindsight, a subject of great controversy. ${ }^{1}$ As American law began its earnest development of First Amendment jurisprudence in the twentieth century, ${ }^{2}$ a number of scholars and jurists began to recognize the confluence of these two areas of law. ${ }^{3}$ Given the novelty of substantive speech rights, however, this confluence remains underexplored. ${ }^{4}$ As a result, most critiques of conspiracy law have little to

1 See Abraham S. Goldstein, Conspiracy to Defraud the United States, 68 Yale L.J. 405, 409 (1959) (contending that defining the crime of conspiracy is far from settled); Francis B. Sayre, Criminal Conspiracy, 35 HARV. L. REv. 393, 393 (1922) (criticizing the doctrine of criminal conspiracy as vague and uncertain); Developments in the Law: Criminal Conspiracy, 72 HARV. L. REV. 920, 922-23 (1959) (highlighting the origin and early development of criminal conspiracy law); Note, Conspiracy and the First Amendment, 79 YALE L.J. 872, 872 (1970) (explaining that cases involving the use of conspiracy law to prevent individuals from joining controversial groups have attained notoriety). Cf. Neal Kumar Katyal, Conspiracy Theory, 112 YALE L.J. 1307, 1309 (2003) (contending that fifty years of critiques aimed at certain features of conspiracy law have shifted the law in the wrong direction); Benjamin F. Pollack, Common Law Conspiracy, 35 GEO. L.J. 328, 328 (1947) (tracing the origin and development of criminal conspiracy).

2 See Lee C. Bollinger \& Geoffrey R. Stone, Dialogue, in Eternally Vigilant: Free Speech IN THE MOdERn ERA 1, 1 (Lee C. Bollinger \& Geoffrey R. Stone eds., 2002) (pinpointing a trilogy of cases in 1919 that first interpreted the principle of freedom of speech and press).

3 See Samuels v. Mackell, 401 U.S. 66, 75 (1971) (Douglas, J., concurring) (dismissing concerns that violent acts are constitutionally protected and should not be evidence of an overt act in furtherance of a conspiracy); Epton v. New York, 390 U.S. 29, 31 (1968) (Douglas, J. dissenting) (considering whether a constitutionally protected right may be used as evidence of an overt act in furtherance of a conspiracy); Thomas I. Emerson, Freedom of Association and Freedom of Expression, 74 YALE L.J. 1, 1 (1964) (writing that freedom of association "is essential to the democratic way of life. At the same time the exercise of this freedom has given rise to novel and troublesome problems. Organizations have grown in size and power, and organizational techniques have achieved a new order of effectiveness"); Geoffrey R. StOne, Perilous Times: Free SPEech in Wartime From the Sedition ACt OF 1798 to the WAR ON Terrorism 481 (2004) ('[T] he crime of conspiracy has routinely been used by prosecutors to 'get' union organizers, political dissenters, radicals, and other 'dangerous' individuals who could not otherwise be convicted of an offense."); David B. Filvaroff, Conspiracy and the First Amendment, 121 U. PA. L. REv. 189, 190 (1972) (acknowledging the infancy of commentary dedicated to the conspiracy-speech combination). Indeed, a number of the major twentieth century criminal speech cases were conspiracy cases. See Yates v. United States, 354 U.S. 298, 300 (1957); Dennis v. United States, 341 U.S. 494, 496 (1951); Hartzel v. United States, 322 U.S. 680, 682 (1944); Schenck v. United States, 249 U.S. 47, 49 (1919); Abrams v. United States, 250 U.S. 616, 617 (1919); Frohwerk v. United States, 249 U.S. 204 (1919).

4 ThOMAs I. EMERSON, The System OF FrEEDOM OF EXPRESSION 402 (1970) ("[T] he law of inchoate crimes developed independently of the law of the First Amendment. The courts have given little explicit consideration to reconciling one set of doctrines with the other.”). 
do with free speech. ${ }^{5}$ When they do, ${ }^{6}$ the concern always involves the use of speech only as the actus reus of agreement and, sometimes, the overt act. ${ }^{7}$

This approach tells only one side of the story. ${ }^{8}$ In conspiracy cases, just as in substantive crime cases, speech is used as evidence of the crime as well as the crime itself. This dual use of speech comprises what I call the "All Purpose Speech Model." In the pages that follow, I argue that this Model accurately describes the use of speech in conspiracy cases, and thereby reveals threats to free speech not recognized by past approaches to the subject.

Unlike past scholarship, ${ }^{9}$ the All-Purpose Speech Model considers speech's multiple uses together because they raise conceptually related concerns. This is so because the functional distinction among agreement, overt act, mens rea, and evidence of these elements is actually an illusion. All of conspiracy's elements and evidence thereof collapse together,

5 Kent Greenawalt, SpeEch, Crime, And The Uses of Language 81 (1989) [hereinafter Greenawalt, Speech, Crime, and The Uses of Language]; Note, Conspiracy and the First Amendment, supra note 1, at 872 (“[C] ourts and commentators have paid surprisingly little attention to the effect of conspiracy law itself on first amendment rights.").

6 EMERSON, supra note 4, at 409 ("It can readily be seen that the law of conspiracy reaches far back into inchoate conduct and has serious implications for the system of freedom of expression." (footnote omitted)).

7 All of the major First Amendment cases considering criminal statutes have taken this view. See Holder v. Humanitarian Law Project, 130 S. Ct. 2705, 2714 (2010); Virginia v. Black, 538 U.S. 343, 363 (2003) (treating a cross burning as the actus reus of the crime); Yates, 354 U.S. at 333; Dennis, 341 U.S. at 575 (Jackson, J., concurring); Hartzel, 322 U.S. at 683; Schenck, 249 U.S. at 48-49; Abrams, 250 U.S. at 618; Frohwerk, 249 U.S. at 205. Speech as crime has also been the lengthy subject of scholarship. See generally GREENAWALt, SPEECH, CRIME, AND THE USES OF LANGUAGE, supra note 5.

8 See EMERSON, supra note 4, at 402 ("[T] he law of inchoate crimes developed independently of the law of the First Amendment. The courts have given little explicit consideration to reconciling one set of doctrines with the other.").

9 Robert P. Faulkner, Evidence of First Amendment Activity at Trial: The Articulation of a Higher Evidentiary Standard, 42 UCLA L. ReV. 1, 5 (1994) (considering the dangers to First Amendment activity when a factfinder could punish a party for such activity); Aziz Z. Huq, The Signaling Function of Religious Speech in Domestic Counterterrorism, 89 TEx. L. REv. 833, 835 (2011) (proposing to evaluate the government's use of religious expression as a proxy for discovering terrorist threats); Peter E. Quint, Toward First Amendment Limitations on the Introduction of Evidence: The Problem of United States v. Rosenberg, 86 YALE L.J. 1622, 1623 (1977) (discussing the role of the First Amendment on the admissibility of certain evidence in trial); Lawrence Rosenthal, The Law Professor as Counterterrorist Tactician, 89 TEX. L. REv. 113, 113 (2011) (responding to Aziz Huq's First Amendment concerns); GeOFFrey R. StOnE, Content Regulation and the First Amendment, in ThE First AMENDMENT FREEDOM OF SPEECH: ITS CONSTITUTIONAL History AND THE CONTEMPORARY DEBATE 153 (Vikram David Amar ed., 2009) (explaining the First Amendment dichotomy between content-neutral and content-based restrictions); Eugene Volokh, Speech as Conduct: Generally Applicable Laws, Illegal Courses of Conduct, "Situation-Altering Utterances," and the Uncharted Zones, 90 CORNELl L. ReV. 1277, 1278 (2005) [hereinafter Volokh, Speech as Conduct (raising concerns about when speech should be stripped of First Amendment protection, because it is, in fact, conduct). 
becoming homogenized. This means that speech as both crime and evidence thereof are subject to problems of speech's ambiguity ${ }^{10}$ and the fact that courts favor the government in conspiracy cases. ${ }^{11}$

The dual uses of speech must be considered together because of the nature of conspiracy's elements and their proof. Conspiratorial agreements can be inferred, ${ }^{12}$ and overt acts, if they are required, ${ }^{13}$ can be proven by the most minor and legal conduct or speech. ${ }^{14}$ Evidence of someone's mens rea and state of mind can amount to evidence of both an agreement and overt act. $^{15}$ This allows and encourages proof of a conspiracy by verbosity of speech evidence; prosecutors are rewarded with convictions by inundating

10 See Eugene Volokh, Crime-Facilitating Speech, 57 STAN. L. REv. 1095, 1185-86 (2005) [hereinafter Volokh, Crime-Facilitating Speech] ("So most speakers of crime-facilitating speech will know that the speech may facilitate crime, but relatively few will clearly intend this. For many speakers, their true mental state will be hard to determine, because their words may be equally consistent with intention to facilitate crime and with mere knowledge. This means that any conclusion about the speaker's purpose will usually just be a guess.").

11 See Thomas I. Emerson, Toward a General Theory of the First Amendment, 72 YALE L.J. 877, 955 (1963) ("The natural balance of forces in society today tends to be weighted against individual expression."); see also Goldstein, supra note 1, at 412 (noting how the ambiguous nature of a conspiracy makes it difficult for defendants to object to evidence on relevance grounds); Note, Conspiracy and the First Amendment, supra note 1, at 875 (explaining that the broad contours of conspiracy law yield "chaotic procedures which favor the prosecution's case"); Note, The Objects of Criminal Conspiracy-Inadequacies of State Law, 68 HARV. L. REV. 1056, 1056 (1955) (noting that conspiracy law allows prosecutors to sidestep certain technical impediments to conviction).

12 American Tobacco v. United States, 328 U.S. 781, 809-10 (1946); United States v. Lopez, 979 F.2d 1024, 1029 (5th Cir. 1993); United States v. Hegwood, 977 F.2d 492, 497 (9th Cir. 1992); United States v. Simon, 839 F.2d 1461, 1469 (11th Cir. 1988); SIR RoberT SAMuel Wright, The LaW of Criminal Conspiracies AND AgreEments 54 (1873) (" $[\mathrm{G}]$ enerally speaking, there need not be any actual meeting or consultation, and that the agreement is to be inferred from acts furnishing a presumption of a common design.").

13 Title 21 drug conspiracies, for example, require no overt act, United States v. Shabani, 513 U.S. 10, 11 (1994); United States v. Pumphrey, 831 F.2d 307, 308 (D.C. Cir. 1987), nor do some conspiracies to provide material support to a foreign terrorist organization, see 18 U.S.C. § 2339B (2006); United States v. Abdi, 498 F. Supp. 2d 1048, 1064 (S.D. Ohio 2007), nor conspiracies to commit money laundering, Whitfield v. United States, 543 U.S. 209, 211 (2005).

14 See United States v. Scallion, 533 F.2d 903, 911 (5th Cir. 1976) (traveling to another city is an overt act); Bartoli v. United States, 192 F.2d 130, 132 (4th Cir. 1951) (making a phone call is an overt act); Goldman v. United States, 245 U.S. 474, 477 (1918) (finding sufficient evidence of an overt act to allow the jury to rule); EMERSON, supra note 4, at 409 (explaining that in conspiracy law, the overt act "need not consist of action and tends to be a mere fiction").

15 See Shabani, 513 U.S. at 16; Jens David Ohlin, Joint Intentions to Commit International Crimes, 11 CHI. J. INT'L L. 693, 695 (2011) (“A criminal agreement provides externalized evidence that the parties intend for the crime to be committed."). 
juries with mounds of "bad" sounding speech ${ }^{16}$ — "bad" speech being that which sounds indicative of criminal activity, but may or may not actually be so. ${ }^{17}$ The evidentiary distinction between agreement, overt act, mens rea, and evidence of these elements fades; "bad" speech assumes the appearance of relevance to proving all of these things, and amounts to a normatively unacceptable blunderbuss approach ${ }^{18}$ to evidence that implicates free speech concerns. ${ }^{19}$ Put another way, in conspiracy trials, speech is the sole necessary building block, which works to prove conspiracy's homogenized set of ostensibly distinct elements.

By accurately describing the use of speech in conspiracy cases, the AllPurpose Speech Model reveals threats to free speech that have not been recognized under the prior unipolar approach. Kent Greenawalt, for example, has dismissed the concern, writing, "no one supposes that the criminal law of conspiracy raises serious First Amendment problems. ${ }^{20}$ This makes sense if speech as the crime of conspiracy and speech as evidence thereof are treated separately: on one hand, there is obvious value to criminalizing certain conspiracies, ${ }^{21}$ and on the other, as Greenawalt writes, "freedom to say what one feels and believes and hopes to do does not constitute freedom from use of one's statements as evidence.,"22

16 See Note, Conspiracy and the First Amendment, supra note 1, at 878 ("[T] he volume of evidence produced by a trial of several defendants may overwhelm the jury.").

17 See Huq, supra note 9, at 837 (questioning reliability of religious speech as a proxy for determining potential terror threats); Quint, supra note 9, at 1636 (questioning reliability of pro-communism speech as an indication of a illegal act by the speaker).

18 This approach arises in part from " $t]$ he fact that it is almost impossible to supply a correct definition of the crime" of conspiracy, because of the "unsettled" law on the subject, Pollack, supra note 1 , at 330 , and that conspiracy law "is so vague that it almost defies definition." Krulewitch v. United States, 336 U.S. 440, 446 (1949) (Jackson, J., concurring). See also Note, The Objects of Criminal Conspiracy-Inadequacies of State Law, supra note 11, at 1056 ("[T] he objects of conspiracy... are defined so vaguely and broadly in the majority of states that both predictability of what will constitute an offense and objectivity by the courts in applying the law have been greatly undermined." (footnote omitted)).

19 Although he was concerned with the problem of vicarious liability, not speech, Jens David Ohlin has explored, as I do here, the same underlying problem that important distinctions fundamental to criminal law principles have faded in the conspiracy law context. See generally Jens David Ohlin, Group Think: The Law of Conspiracy and Collective Reason, 98 J. CRIM. L. \& CRIMINOLOGY 147 (2007); see also United States v. Spock, 416 F.2d 165, 188 (1st Cir. 1969) (Coffin, J., dissenting) ("[T]he absence of clear definitions of the elements of conspiracy creates a serious risk. ... [Conspiracy] is ... not well-defined and experience teaches that even its traditional limitations tend to disappear.").

20 Kent Greenawalt, "Clear and Present Danger" and Criminal Speech, in ETERNALly VigiLANT: FREE SPEECH IN THE MODERN ERA, supra note 2, at 96, 111.

21 See Katyal, supra note 1 (arguing that recent moves towards undermining conspiracy law are a mistake).

22 Greenawalt, SpeEch, CRIME, AND The Uses Of LANGUAGe, supra note 5, at 245. 
This approach assumes a separation between speech-as-evidence and the crime it is meant to prove. It employs what Thomas I. Emerson called the "expression-action analysis" ${ }^{23}$ to the use of speech in criminal cases, which arises when the government either seeks to make speech itself an inchoate crime or when it seeks to use speech as evidence of a "crime of action." ${ }^{24}$ Although Emerson noted that this analysis becomes particularly problematic in the context of conspiracy, ${ }^{25}$ he made clear that his expression-action analysis was oriented toward the use of speech either as crime or as evidence of a substantive crime. ${ }^{26}$ The expression-action analysis does not address the problems associated with speech being used simultaneously as the crime itself and evidence thereof. In other words, the homogenization of conspiracy's elements and evidence thereof eliminates the distinction between expression-as-evidence and action-as-element. Expression becomes the crime itself, and so conspiracy directly threatens free speech. ${ }^{27}$

In this way, the All-Purpose Speech Model reveals conspiracy's threats to free speech and, possibly, the First Amendment. There is an important difference between the two. ${ }^{28}$ Greenawalt distinguishes between "the

23 Emerson's expression-action analysis is distinct from his argument that "the essence of a system of freedom of expression lies in the distinction between expression and action." Emerson, supra note 11. This is a nuance that has gone undetected. The expressionaction analysis is concerned with speech being used to prove a substantive criminal action, and so falls outside of this Article's central concern. Emerson's discernment that speech can be "expression" or "action" is a typology of speech and so is a different inquiry. His two-part typology is, however, referenced in this article, as it closely tracks what I call "operational" and "aspirational" speech, discussed in detail below.

24 EMERSON, supra note 4.

25 Id. See also Emerson, supra note 3, at 23-24.

26 See EMERSON, supra note 4, at 405, 406, 411-12 (identifying that First Amendment issues arise "when the government seeks to use expression either as evidence that the subsequent action took place or as evidence of the state of mind of the person who engaged in the action. ... Perhaps the best formulation that can be made ... is that there must be an unusually close connection between the expression and the action, that the expression must be an integral part of the action, not remote or unattached.... [T] he government might be required to establish the action part of the offense before it would be allowed to prove any elements of expression. ... Proof of a crime cannot be evidenced by 'protected expression' that is so remote from action, or so subject to risk of penalty, that freedom of expression is curtailed").

27 See LARRY AlEXANDER, Is THERE A Right OF FREEDOM OF EXPRESSION? 8 (2005) (“[W] hen the government threatens speaker $\mathrm{S}$ with punishment if he attempts to give certain information or express certain opinions to audience A, we are tempted to regard this as a violation of S's right to freedom of expression."). This is merely a positive statement, and says nothing about the reliability of speech to indicate an actual conspiracy, or, if a criminal conspiracy actually exists, whether and to what extent speech should be admissible to prove it. These issues are approached in this article, but are ultimately separate inquiries deserving of their own attention.

28 See Frederick Schauer, Free SPEech: A PHILOSOPHICAL ENQUiRY 7 (1982) (“[T]he analysis of freedom of speech can and should be separated from questions about the limits of governmental authority in a broader sense."). 
political principle of freedom of speech" and "the constitutional protection" of speech under the First Amendment. ${ }^{29}$ Legislatures, hopefully, look to principles of free speech when crafting law, which may protect more speech than the First Amendment requires. ${ }^{30}$ Courts, in turn, provide a First Amendment floor of protection that also may protect speech against occasional legislative encroachments. ${ }^{31}$

This Article argues that conspiracy law threatens free speech, i.e. speech that is valuable in light of recognized rationales for protecting speech, but may not be constitutionally protected. Recognizing the novelty of its argument and the political, evidentiary, and conceptual challenges of placing conspiracy charge-related speech under First Amendment protection, ${ }^{32}$ I reserve that inquiry for later work, so that it may be given the attention it deserves. ${ }^{33}$

To make its argument, this Article sets forth a new typology of speech. Current typologies do not respond as well as they might to the use of speech in conspiracy cases. These typologies are Kent Greenawalt's tripartite structure of speech, which includes situation-altering utterances, weak imperatives, and assertions of fact and value,$^{34}$ and the category of speech "integral" to criminal conduct. ${ }^{35}$ I combine these two systems to produce a more useful four-part typology of speech, which includes what I call operational and aspirational speech, ${ }^{36}$ and speech that is necessary, facilitative, or related to the criminal conduct alleged. I call this the Conspiracy Specific Speech Typology. It illustrates the relevant kinds of speech used in conspiracy cases and reveals when speech is used in normatively acceptable, uncontroversial ways, and when it is used in ways that threaten free speech.

To these ends, this Article proceeds in four main parts. In Part II, I provide a factual context. I discuss two post-9/11 terrorism-related

29 Greenawalt, SPEech, Crime, AND The Uses of LANGUAGE, supra note 5, at 42.

$30 \quad I d$. at 166

31 See id. (explaining that courts will rule unconstitutional statutes that have an unconstitutional application that legislatures overlooked).

32 See Frederick Schauer, First Amendment Opportunism, in ETERnALly ViGILANT: FrEe SPEECH IN THE MODERN ERA, supra note 2, at 175, 186, 195.

33 This inquiry, indeed, would require substantial work. The interest in public safety is central and legitimate, and a coherent theory of free speech in the conspiracy context is lacking. Without that theory, any arguments in favor of free speech-or public safety, for that matter-are likely to be arbitrary. See ALEXANDER, supra note 27, at 23.

34 Greenawalt, SPEECH, CRIME, AND The Uses OF LANGUAGE, supra note 5, at 43, 57.

35 See United States v. Stevens, 130 S. Ct. 1577, 1586 (2010) (quoting Giboney v. Empire Storage \& Ice Co., 336 U.S. 490, 498 (1949)).

36 For a closely related concept, see EMERSON, supra note 4, at 18 (arguing that free speech inquiries "must be directed toward ascertaining what is expression, and therefore to be given the protection of expression, and what is action, and thus subject to regulation"). 
conspiracy cases, on one of which, United States $v$. Mehanna, I was a member of the defense team. ${ }^{37}$ I also discuss speech related to jihad, communism, and hip-hop music.

In Part III, I present the All-Purpose Speech Model by discussing the intersection of speech and conspiracy. In Part IV, I deconstruct Greenawalt's tripartite structure of speech and the category of speech integral to criminal conduct, and present the Conspiracy Specific Speech Typology.

In Part V, I briefly set forth the familiar three-level structure of speech protection, which includes what most scholars call high-value speech, lowvalue speech, ${ }^{38}$ and speech not believed to be governed by First Amendment considerations. $^{39}$ I bring all of the parts of this Article together and use this structure to illustrate further how conspiracy law threatens free speech. In the conclusion, I point to a possible future in which First Amendment requirements bear heavily on conspiracy law. This future, I suggest, is based on the Brandenburg line of cases and a reconceiving of the dangers associated with criminal conspiracies.

37 United States v. Mehanna, No. 09-10017-GAO, 2011 WL 3652524 (D. Mass. Aug. 19, 2011).

38 See Sonia K. Katyal, Trademark Intersectionality, 57 UCLA L. REv. 1601, 1608 (2010) (arguing that trademarks often overlap between constitutionally "low-value" and "highvalue" speech designations); David A. Strauss, Freedom of Speech and the Common-Law Constitution, in ETERNALLy Vigilant: Free SPEECH IN THE MODERn ERA, supra note 2, at 32, 37 (describing "low-value" categories of speech such as, inter alia, obscenity, commercial speech, false and defamatory statements, "fighting words," perjury, blackmail); Sonja R. West, Awakening the Press Clause, 58 UCLA L. REv. 1025, 1049-50 (2011) (observing that defenders of free speech often challenge abridgments of "lowvalue" or "fringe" speech as a bulwark against potential infringments of core, "high-value" speech); see also CASS R. Sunstein, DEMOCRACY AND THE Problem OF Free SPEECH 122 (1993) (describing the "Madisonian ideal" which posits a two-tier First Amendment and affords more protection to political speech than nonpolitical speech).

39 See Chaplinsky v. New Hampshire, 315 U.S. 568, 572 (1942) (stating that words "which by their very utterance inflict injury or tend to incite" a breach of the peace, such as lewd and obscene, libelous, or "fighting" words, do not garner First Amendment protection); David A. Strauss, Freedom of Speech and the Common-Law Constitution, in ETERNALly Vigilant: Free SpeEch In the Modern ERA, supra note 2, at 32, 37; Richard A. Posner, The Speech Market and the Legacy of Schenck, in Eternally Vigilant: FreE SPEech in THE MODERN ERA, supra note 2, at 120, 132. 


\section{THE FACTUAL CONTEXT}

\section{A. Sami Omar Al-Hussayen}

Sami Omar Al-Hussayen was a doctoral student in computer science at the University of Idaho ${ }^{40}$ when, in 2004, he was charged with providing and conspiring to provide material support to a designated foreign terrorist organization. $^{41}$

His indictment indicated that between 1994 and 2003, Al-Hussayen provided "expert advice and assistance, communications equipment, currency, monetary instruments, financial services and personnel. ${ }^{.42}$ He did so "by, among other things, creating and maintaining internet websites and other internet media designed to recruit mujahideen and raise funds for violent jihad in Israel, Chechnya and other places." ${ }^{43}$

The indictment detailed that Al-Hussayen "helped create, operate and maintain various websites and internet media associated with" certain Islamic organizations ${ }^{44}$ that, said the government, had connections to Hamas. These websites and Al-Hussayen's assistance were used to support and justify violent jihad. ${ }^{45}$ For example, Al-Hussayen "published or broadcasted a wide variety of speeches, lectures and articles justifying and glorifying violent jihad, as well as graphic videos depicting mujahideen and other subjects relating to violent jihad, with the intent to inspire viewers to engage in and provide financial support for violent jihad."

One of the websites with which Al-Hussayen was involved contained a hyperlink to another website that solicited donations to Hamas. ${ }^{47}$ On that same website and another, users were "invited to sign up for an internet email group, maintained and moderated by Al-Hussayen and others, in order to obtain 'news' of violent jihad on Chechnya." ${ }^{48}$ As an administrator, AlHussayen had the authority to accept, retain and delete messages posted to the group. ${ }^{49}$ Materials distributed on the site included the "Virtues of Jihad $^{, 50}$ and instructions on how to train for jihad. ${ }^{51}$

$\begin{array}{ll}40 & \text { Maureen O'Hagan, A terrorism case that went awry, SEATTLE TIMES, Nov. 22, 2004, available } \\ \text { at seattletimes.com/html/localnews/2002097570_sami22m.html. } \\ 41 \\ \text { Second Superseding Indictment at 2, United States v. Al-Hussayen, No. CR 03-0048-C-EJL } \\ \text { (D. Idaho Mar. 4, 2004). } \\ 42 & \text { Id. } \\ 43 & \text { Id. } \\ 44 & \text { Id. at } 5 . \\ 45 & \text { Id. } \\ 46 & \text { Id. } \\ 47 & \text { Id. at } 8 . \\ 48 & \text { Id. at } 9 . \\ 49 & \text { Id. } \\ 50 & \text { Id. }\end{array}$ 
At trial, the government argued that Al-Hussayen had a "dual persona. One face to the public and a private face of extreme jihad., ${ }^{, 52}$ It defined "violent jihad" as

the taking of action against persons or governments that are deemed to be enemies of a fundamentalist version of Islam. Historically, violent jihad has included armed conflicts and other violence in numerous areas of the world, including Afghanistan, Chechnya, Israel, the Philippines and Indonesia. The armed conflicts in these geographic areas and elsewhere have involved murder, maiming, kidnaping, and destruction of property. ${ }^{53}$

The indictment and the government's opening statement led one juror to believe that Al-Hussayen was "going to be in jail for life."

At trial, the government argued that Al-Hussayen's “'fingerprints were intricately involved in the building of Web sites that called on young people to go and kill themselves' and to make donations for attacks." ${ }^{55}$ It emerged, however, there was no evidence that the websites actually recruited people, or that Al-Hussayen believed their jihadi message. ${ }^{56}$ Furthermore, the defense argued that the hyperlinks from Al-Hussayen's website to the website that facilitated donations to Hamas were removed before AlHussayen became involved. ${ }^{57}$ Finally, the websites that Al-Hussayen volunteered for were those of Muslim charities. ${ }^{58}$ The government alleged that buried deep within them were a handful of violent messages-written by people other than Al-Hussayen-that encouraged attacks on the United States and donations to terrorist organizations. ${ }^{59}$

By the end of the trial, the juror who thought Al-Hussayen would be going away for life had changed his mind. In the course of the trial, he had heard no evidence that Al-Hussayen supported terrorism. ${ }^{60}$ The government's case, he said, "was a real stretch." acquitting Al-Hussayen of all the terrorism charges after only a few hours of deliberation. $^{62}$

Id. at 10 .

O'Hagan, supra note 40.

Second Superseding Indictment at 5, United States v. Al-Hussayen, No. CR 03-0048-C-EJL (D. Idaho Mar. 4, 2004).

O'Hagan, supra note 40.

Id.

Id.

Id.

Id.

Id.

Id.

Id.

$I d$. 


\section{B. Tarek Mehanna}

Tarek Mehanna was found guilty in December 2011 of providing and conspiring to provide material support to al Qaeda, and conspiracy to kill in a foreign country. ${ }^{63}$ These charges were based on two factual allegations. First, Mehanna was charged with conspiracy based on a 2004 trip he took to Yemen, the purpose of which the government alleged was to find and train at a terrorist training camp so that he could proceed to Iraq to fight against United States forces. ${ }^{64}$ Second, Mehanna was charged with conspiracy to provide and actually providing material support based on his translation of a publicly available document ${ }^{65}$ called 39 Ways to Serve and Participate in Jihad $^{66}$ and a "jihadi video" called The Expedition of Umar Hadid, ${ }^{67}$ also publicly available. $^{68}$ There was no evidence that Mehanna performed these translations at al Qaeda's behest, or that he had any contact at all with al Qaeda. ${ }^{69}$

The government argued that Mehanna's translation work was itself material support, because it encouraged others to fight jihad and otherwise support al Qaeda. ${ }^{70}$ This translation work, as well as instant messages between Mehanna and others, ${ }^{71}$ jihadi videos, ${ }^{72}$ and images of $9 / 11$ and

63 Jury Verdict Form, United States v. Mehanna, No. 09-10017-GAO (D. Mass. Dec. 20, 2011).

64 Second Superseding Indictment at 5, 13, United States v. Mehanna, No. 09-CR-10017GAO (D. Mass. June 17, 2010).

65 See Full Text of "39 Ways to Serve and Participate", InTERnet ARCHIVE, http://www.archive.org/stream/39WaysToServeAndParticipate/39WaysToServeAndParti cipateInJihad_djvu.txt (last visited Oct. 23, 2012).

66 Second Superseding Indictment at 17, United States v. Mehanna, No. 09-CR-10017-GAO (D. Mass. June 17, 2010).

$67 \quad$ Id. at $15-16$.

68 The Expedition of Shaykh 'Umar Hadid, LIVE LEAK, http://www.liveleak.com/ view?i=5e5_1182736217 (last visited Jan. 13, 2012).

69 Rick Holmes, Tarek Mehanna, political prisoner, Holmes \& COMPANY: A BLOG FOR INDEPENDENT MINDS (Dec. 20, 2011), http://blogs.wickedlocal.com/holmesandco/ 2011/12/20/tarek-mehanna-political-prisoner/\#axzzljMHdJpOD; Adam Serwer, I Guess Posting Videos Online Can Make You a Terrorist, MOTHER JONES (Dec. 20, 2011), http://motherjones.com/mojo/2011/12/i-guess-posting-videos-online-can-make-youterrorist; Daily Coverage of Tarek Mehanna's Trial, 39 Ways to Serve and Participate in Jihad, FREETAREK.COM, http:// freetarek.wordpress.com/the-defendant/discussion-of-thegovernments-proffer/39-ways-to-serve-and-participate-in-jihad/ (last visited Jan. 13, 2012).

70 Second Superseding Indictment at 6, 8, 17, United States v. Mehanna, No. 09-CR-10017GAO (D. Mass. June 17, 2010).

71 Julia Spitz, Mehanna trial closings raise a familiar question, MetroWest DAILY News (Dec. 17, 2011, 1:26 AM), http://www.metrowestdailynews.com/features/x2140450734/SpitzMehanna-trial-closings-raise-a-familiar-question.

72 Patrick Tracey, Convicted for words, not deeds, SALON (Dec. 21, 2011, 8:55 AM), http://www.salon.com/topic/tarek_mehanna/. 
Osama bin Laden, ${ }^{73}$ were all "bad" speech that was introduced to show Mehanna's state of mind ${ }^{74}$ as well as infer the alleged conspiracy's agreement and overt act.

\section{Beyond Terror}

The results of these cases were indictments or convictions for activity that may or may not have been actual criminal conspiracies, may or may not have ripened into actual conduct, an expansion of conspiratorial combinations beyond what traditional conspiracy law recognizes, and a fear-driven milieu that sees terrorism as "different" and thus favors the government. ${ }^{75}$ These phenomena are not new to the 9/11 era, nor are they restricted to terrorrelated cases. The First Amendment conspiracy cases emerging in the wake of World War I can be seen as the results of anti-socialist preventive policing, ${ }^{76}$ just as the post-World War II cases ${ }^{77}$ are now recognized as part of an anti-communist witch hunt. ${ }^{78}$ The doctrine of variance, designed to address these prosecutorial missteps, was established in Kotteakos $v$. United States, a fraud conspiracy case. ${ }^{79}$

Consider also the recent First Circuit opinion in United States $v$. Dellosantos. $^{80} \quad$ In that case, the government charged the defendant with conspiracy to distribute narcotics. ${ }^{81}$ The conspiracy allegedly included a total of eighteen people. ${ }^{82}$ The defendant was convicted after a trial of conspiracy to distribute cocaine and marijuana. ${ }^{83}$

73 Laurel J. Sweet, Jury convicts Sudbury man of terror plot, BOSTON HERALD (Dec. 20, 2011), http://bostonherald.com/news/regional/view/2011_1220jury_reaches_verdict_in_tarek _mehanna_terror_trial.

74 See Milton J. Valencia, Tarek Mehanna guilty of terror charges, Boston GLOBE (Dec. 20, 2011), http://www.bostonglobe.com/metro/2011/12/20/tarek-mehanna-found-guiltyall-terror-charges/chpbwimRMbvdNMOladJ08J/story.html?camp=pm.

75 See Note, Conspiracy and the First Amendment, supra note 1, at 872 ("Throughout various periods of xenophobia, chauvinism, and collective paranoia in American history, conspiracy law has been one of the primary governmental tools employed to deter individuals from joining controversial political causes and groups." (footnote omitted)).

76 Abrams v. United States, 250 U.S. 616 (1919); Frohwerk v. United States, 249 U.S. 204 (1919); Schenck v. United States, 249 U.S. 47 (1919).

77 Yates v. United States, 354 U.S. 298, 300 (1957); Dennis v. United States, 341 U.S. 494, 497 (1951).

78 Mark Brodin, What One Lawyer Can Do for Society: Lessons from the Remarkable Career of William P. Homans Jr., 46 New ENG. L. REv. 37, 43 (2011); Erik Luna, Criminal Justice and the Public Imagination, 7 OHIO ST. J. CRIM. L. 71, 95 (2009); Dara L. Schottenfeld, Comment, Witches and Communists and Internet Sex Offenders, Oh My: Why It Is Time to Call Off the Hunt, 20 ST. THOMAS L. REv. 359, 365 (2008).

$79 \quad 328$ U.S. 750, 752 (1946).

$80 \quad 649$ F.3d 109 (1st Cir. 2011).

81 Id. at 110

$82 I d$.

83 Id. at 111. 
On appeal, the First Circuit determined that two conspiracies operated, one that included distribution of cocaine, and another that included distribution of cocaine and marijuana. ${ }^{84}$ The Court found that Dellosantos was a member of the cocaine-only conspiracy, ${ }^{85}$ and so vacated his conviction for distributing both drugs. ${ }^{86}$

In proving that Dellosantos conspired to distribute both marijuana and cocaine, the government,

under the guise of its single conspiracy theory... subjected the Defendants to voluminous testimony relating to unconnected crimes in which they took no part. This situation created a pervasive risk of "evidentiary spillover," where the jury might have unfairly transferred to the Defendants the guilt relating to the other sixteen individuals. Specifically, there was a pervasive risk that such transference of guilt might have led the jury to find the Defendants guilty of joining the conspiracy... despite the fact that the evidence was insufficient to support such a finding. ${ }^{87}$

In light of this, the Court concluded that "there should be little question that the jury's decision to find the Defendants guilty of joining the conspiracy... was influenced by the plethora of evidence implicating the other sixteen indicted co-defendants. ${ }^{, 88}$

\section{Communism, Hip-Hop, and Jihad}

The All-Purpose Speech Model is a problem because of the "bad" and inaccurate meaning given to the speech used. The government can seek to impose such meanings at trial or, where the defendant is charged with a conspiracy related to his association with a suspect group, a priori assumptions of "badness" may be applied to his speech. ${ }^{89}$

Justice Black, writing in Yates $v$. United States, leveled this criticism of the dubiously relevant use of speech in conspiracy trials:

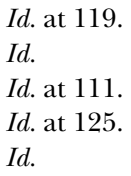

See Herbert Wechsler et al., The Treatment of Inchoate Crimes in the Model Penal Code of the American Law Institute: Attempt, Solicitation, and Conspiracy, 61 Colum. L. REv. 571, 627 (1961) ("The problem is in preventing legitimate agitation of an extreme or inflammatory nature from being misinterpreted as solicitation to crime. It would not be difficult to convince a jury that inflammatory rhetoric in behalf of an unpopular cause is in reality an invitation to violate the law rather than an effort to seek its change through legitimate criticism. Minority criticism has to be extreme in order to be politically audible, and if it employs the typical device of lauding a martyr, who is likely to have been a lawbreaker, the eulogy runs the risk of being characterized as a request for emulation."). 
The kind of trials conducted here are wholly dissimilar to normal criminal trials. Ordinarily these "Smith Act" trials are prolonged affairs lasting for months. In part this is attributable to the routine introduction in evidence of massive collections of books, tracts, pamphlets, newspapers, and manifestoes discussing Communism, Socialism, Capitalism, Feudalism and governmental institutions in general, which, it is not too much to say, are turgid, diffuse, abstruse, and just plain dull. Of course, no juror can or is expected to plow his way through this jungle of verbiage. The testimony of witnesses is comparatively insignificant. Guilt or innocence may turn on what Marx or Engels or someone else wrote or advocated as much as a hundred or more years ago. Elaborate, refined distinctions are drawn between "Communism," "Marxism," "Leninism," "Trotskyism," and "Stalinism." When the propriety of obnoxious or unorthodox views about government is in reality made the crucial issue, as it must be in cases of this kind, prejudice makes conviction inevitable except in the rarest circumstances.

Communist-related speech in the 1950s carried "bad" speech connotations that may or may not have portended the danger their stigma suggested. $^{91}$ Hip-hop lyrics have similarly been used against defendants in drug conspiracy trials. In one case, a twenty-minute video of the defendant rapping with another man about his involvement in the drug trade was used to prove his involvement in a narcotics conspiracy, ${ }^{92}$ even though no drugs were actually seized. $^{93}$ The defendant testified that rapping was his art and that his lyrics were not true, but were meant to draw a response from the crowd. ${ }^{94}$ The Eighth Circuit found that admission of the video did not violate the defendant's rights. ${ }^{95}$

In another case, the government introduced a rap video it had found on YouTube during the course of a defendant's drug conspiracy trial. ${ }^{96}$ The Eleventh Circuit found error in admission of this video, in part because the defendant was not in it, had not authored the lyrics, and had not adopted the views expressed. ${ }^{97}$

90354 U.S. 298, 339 (1957) (Black, J., concurring in part and dissenting in part).

91 See Huq, supra note 9, at 891-92 (observing that courts in the 1950s and 60s, concerned with anti-Communist overreach, crafted criminal conspiracy doctrine such that associational conduct could only be criminally punishable where the defendant had "specific intent" to commit the crime ascribed to the associated organization, thus preventing juries from "using unpopular associational ties as a proxy for dangerousness").

92 United States v. Moore, 639 F.3d 443, 445, 448 (8th Cir. 2011).

93 Id. at 446

$94 \quad I d$.

$95 \quad I d$. at 448.

96 United States v. Gamory, 635 F.3d 480, 488 (11th Cir. 2011).

$97 \quad$ Id. at 493. 
The government's definition of jihad in the Al-Hussayen case and other cases also illustrates this a priori assumption of "badness." ${ }^{98}$ In fact, jihad can mean a number of things. It can mean a body of legal doctrine pertaining to legitimate warfare $;{ }^{99}$ "disputation and efforts made for the sake of God and in his cause"; ${ }^{100}$ "'internal,' 'spiritual' jihad [that is] every bit as old as its 'external,' 'fighting' counterpart"; ${ }^{101}$ and preaching the word of Islam. ${ }^{102}$

For charges that include a substantive act, the All-Purpose Speech Model is less concerning, both because actual conduct vouches for speech's relevance and because the government has less need to use words like jihad in simplified, exaggerated, and unsupported ways. ${ }^{103}$ This is why most observers are not troubled ${ }^{104}$ by the Second Circuit's rejection of the defendant's First Amendment claim in United States v. Rahman. ${ }^{105}$ Rahman was the Muslim cleric found guilty of seditious conspiracy for plotting to bomb the World Trade Center in 1993 and assassinate Egyptian President Hosni Mubarak. ${ }^{106}$ Although Rahman engaged only in speech, it was closely tied to actual conduct, not least of which was the actual bombing of the World Trade Center. ${ }^{107}$ Because there was actual conduct, the government had no need to advance a dubiously reliable definition of jihad. Rahman's own use of jihad, in fact, clearly confirmed his criminality. He exhorted his

98 Criminal Indictment (Third Superseding) at 1-2, United States v. Sadequee, No. 1:06-CR147-WSD-GGB (N.D. Ga. Dec. 9, 2008) (“'Violent jihad,' as used in this Indictment, refers to planning, facilitating, preparing for, and engaging in acts of physical violence, including murder, kidnaping, maiming, assault, and damage to and destruction of property, against civilian and government targets, in purported defense of Muslims or retaliation for acts committed against Muslims, in the United States and in foreign nations."); Superseding Indictment at 2, United States v. Hassoun, No. 04-60001-CRCOOKE (S.D. Fla. Nov. 17, 2005) ("As used in this Superseding Indictment, the terms 'violent jihad' or 'jihad' include planning, preparing for, and engaging in, acts of physical violence, including murder, maiming, kidnapping, and hostage-taking. The term 'mujahideen' means warriors engaged in violent jihad.").

99 Michael Bonner, JiHAd In Islamic History: Doctrines ANd Practice 3 (2006); Malise RuthVEN, ISLAM: A VERY SHORT INTRODUCTION (1997).

100 BONNER, supra note 99, at 21.

$101 \quad I d$. at 22.

102 DAVID COOK, UNDERSTANDING JIHAD 122 (2005).

103 For examples of indictments invoking the word jihad negatively, see Superseding Indictment, United States v. Siraj, No. 05-104 (S-1) (NG) (E.D.N.Y. Mar. 14, 2006), and Indictment, United States v. Mustafa, No. S2 04 Cr. 356 (JFK) (S.D.N.Y Feb. 6, 2006).

104 See, e.g., Joseph Grinstein, Jihad and the Constitution: The First Amendment Implications of Combating Religiously Motivated Terrorism, 105 YALE L.J. 1347, 1365 (1996); Marc Rohr, Grand Illusion? The Brandenberg Test and Speech that Encourages or Facilitates Criminal Acts, 38 Willamette L. Rev. 1, 26 (2002); John F. Wirenius, Brigaded With Action: Undirected Advocacy and the First Amendment, 32 SetOn HALL L. Rev. 299, 311 (2002).

105189 F.3d 88 (2d Cir. 1999).

106 Id. at 103-04.

107 Id. at 123-24. 
followers to " do jihad with the sword, with the cannon, with the grenades, with the missile ... against God's enemies." "108

Contrast Rahman's definition of jihad with that set forth by one Islamic scholar: "the believer may undertake jihad 'by his heart; his tongue; his hands; and by the sword'-the foremost of these being the first." ${ }^{109}$ Another scholar notes that some Islamic traditions indicate that the best type of jihad is speaking the truth to an iniquitous ruler or tyrant. ${ }^{110}$ The Quran, in turn, states that a Muslim should "[c]ombat the polytheists with your possessions, your selves, and your tongues."

The point is that talk of jihad, like communist tracts and hip-hop, is often a priori assumed to be probative of criminal intent or activity. ${ }^{112}$ This is separate from but related to the All-Purpose Speech Model. It is related because the dual uses of speech inherent in the Model raise serious questions of process outcome reliability. ${ }^{113}$ When speech is used as evidence and as crime (with the same speech often used for both), confidence in a guilty verdict may be undermined. ${ }^{114}$ The a priori assumption is also separate from the All-Purpose Speech Model because the Model would exist whether language were saddled with an a priori "bad" assumption, or it was given a "bad" meaning by the prosecutor at trial. The practical result is qualitatively the same; "bad" speech is admitted that is not as probative as it appears. A priori assumptions simply make the speech much more damning and difficult to counter.

108 Id. at 104

109 RUTHVEN, supra note 99, at 118.

110 CoOK, supra note 102, at 33-34.

111 Id. at 34.

112 Fawaz A. Gerges has argued, for example, that:

[I]t is misleading and counterproductive to lump all jihadis under the rubric of $\mathrm{Al}$ Qaeda and its affiliates, because they account for only a tiny minority within the jihadi movement... [A] huge block within the jihadi movement ... vehemently rejected Al Qaeda's strategy and methods and broke with their transnationalist counterparts for good.

FAWAZ A. GERGES, THE FAR ENEMY: Why JiHAD Went GLOBAL 27 (2005).

Similarly, Michael Bonner has argued that "we encounter the temptation of allowing the notion of jihad to apply to almost everything - a temptation that is best for us to avoid." BONNER, supra note 99, at 11.

113 Note, The Objects of Criminal Conspiracy-Inadequacies of State Law, supra note 11, at 1059 (claiming that "[s]erious problems of vagueness and lack of predictability arise ... when the objects of conspiracy are defined" generally).

114 It should be noted that outcome reliability problems in the context of the All-Purpose Speech Model compound the problems observed in conspiracy from more traditional vantage points. In 1873, Robert Samuel Wright observed:

The [apparently conspiratorial] concert may commonly be a mere simultaneity arising from the fact that one real or supposed grievance happens to press at the same time on many persons; and in such a case an interchange of complaints is inevitable, and does not of itself involve anything which it can be desirable to punish.

WRIGHT, supra note 12 , at 35-36. 
In pursuing inchoate offenses, less actual conduct means that the government must increasingly rely on speech to be simultaneously the agreement, overt act, evidence of these elements, and evidence of mens rea. ${ }^{115}$ This encourages prosecutors to stretch the meaning of language. Jihad has come to mean terrorism, and not only in the government's eyes. ${ }^{116}$ Groups like al Qaeda also have practically redefined the word to mean abject and raw terrorism. ${ }^{117}$

These varied meanings, and the government's interest in avoiding another $9 / 11$, lead to disturbing linguistic shapeshifting. If a defendant has been critical of the U.S. Government, he is not speaking truth to a tyrant but is evincing criminal intent. If someone claims that he wants to spread the word of Islam, this does not mean that he wants to engage in proselytizing, but that he wants to engage in fighting. If someone argues that Chechen rebels are freedom fighters and that Russian soldiers in that region are war criminals, it means that he believes that the 9/11 hijackers were freedom fighters and the people killed in those attacks got what they deserved. ${ }^{118}$ If someone argues that the insurgencies in Iraq and Afghanistan are justified to defend these countries, then that person must intend to kill U.S. service people if given the chance. When someone uses the word jihad, that person must support terrorism and must himself be a criminal. If he has not taken any action, his crime is conspiracy.

The challenge, then, is to embed language into its milieu by deeply understanding it. In a Seventh Circuit drug case, for example, in which a rap lyric was introduced, the defendant argued that this music "'constitutes a popular musical style that describes urban life' ... [and] the reality around its author." ${ }^{119}$ The Seventh Circuit responded that the defendant's "knowledge of this reality ... was relevant" to the charged crimes. ${ }^{120}$

In that case, drugs were found in the defendant's luggage, ${ }^{121}$ and so there was little prejudice to introducing the rap lyrics. In light of the AllPurpose Speech Model, however, this case suggests that the government will

115 See United States v. Spock, 416 F.2d 165, 188 n.9 (1st Cir. 1969) (Coffin, J., dissenting in part) ("Counsel for the defendants were faced... with theories that the Call was the agreement and ipso facto proof of the conspiracy .....").

116 GERGES, supra note 112, at 3.

117 Sebastian Gorka, Understanding the jihadis—by way of Sun Tzu, NATIONAL Post, July 17, 2009, at A15.

118 See Gilles Kepel, Jihad: The Trail of Political Islam 2-3 (2002) (describing preparations for the invasion of Afghanistan, stating "American troops were prepositioned in the former Soviet republic of Uzbekistan, an unprecedented event for which the quid pro quo would be giving the Kremlin a free hand in dealing with the Chechen uprising").

119 United States v. Foster, 939 F.2d 445, 456 (7th Cir. 1991).

$120 \quad I d$.

121 Id. at 449. 
give defendants' speech "bad" meanings, even when the government, judge, or jury do not understand the speech $^{122}$ or the meaning of the speech is stretched. People who live in crime-ridden neighborhoods-or in communities that are perceived to be crime-ridden-have a greater incentive to censor themselves than people in safe or apparently safe neighborhoods. Put another way, innocent talk of things like jihad, ${ }^{123}$ communism, and drug dealing can be misconstrued ${ }^{124}$ and result in threats to free speech.

\section{E. World-Wide Communism and the Global Jihad Movement}

Conspiracy law has always struggled to define its borders, and so has given rise to doctrines including the Pinkerton rule on vicarious liability, ${ }^{125}$ multiplicity, ${ }^{126}$ admission of co-conspirators' statements, ${ }^{127}$ and rules to exclude those statements. ${ }^{128}$ The basic question is who is in a conspiracy and who is not. The answer has always lain in whether someone agreed to join. ${ }^{129}$

The conceptual difficulties with proving agreements notwithstanding, ${ }^{130}$ some conspiracy charges stretch the notion of agreement beyond what traditional conspiracy law recognizes. During the anti-communist era, for example, Congress found that:

122 Jason E. Powell, R.A.P.: Rule Against Perps (Who Write Rhymes), 41 RUTGERS L.J. 479, 525 (2009) ("The law has demonstrated its resentment toward rap music for many years in a variety of ways. This is one more method to continue that trend. Presenting violent, misogynistic rap lyrics written by a defendant to a judge and jury who do not understand where they are coming from, and in all likelihood simply have a distaste for rap, is not fair.").

123 Monica K. Miller et al., From Kobe Bryant to Saddam Hussein: A Descriptive Examination and Psychological Analysis of How Religion Likely Affected Twenty-Five Recent High-Profile Trials, 9 FLA. COASTAL L. REV. 1, 18 (2007) (describing jurors as associating jihad with terrorism or violence); see generally Shaheen Sardar Ali \& Javaid Rehman, The Concept of Jihad in Islamic International Law, 10 J. CONFLICT \& SECURITY L. 321 (2005) (arguing that Islam has become one of the most misunderstood religions and is often associated with intolerance, violence, and aggression).

124 One scholar has offered a litany of rap lyrics pointing to their wrongful use as evidence. See Powell, supra note 122.

125 Pinkterton v. United States, 328 U.S. 640, 646-47 (1946).

126 Braverman v. United States, 317 U.S. 49, 53-54 (1942).

127 FED. R. EVID. 801(d) (2) (E).

128 United States v. Gantt, 617 F.2d 831, 845 (D.C. Cir. 1980); United States v. Petrozziello, 548 F.2d 20, 22 (1st Cir. 1977).

129 United States v. Hutto, 256 U.S. 524, 528 (1921); Pettibone v. United States, 148 U.S. 197, 203 (1893); Yates v. United States, 225 F.2d 146, 155 (9th Cir. 1955).

130 The fact that agreements can be inferred, for example, is the subject of criticism. Benjamin E. Rosenberg, Several Problems in Criminal Conspiracy Laws and Some Proposals for Reform, 43 CRIM. LAW BULL. 427 (2007) (addressing "certain problems that are inherent in the law of conspiracy and that occur with great frequency"). 
The Communist movement in the United States is an organization numbering thousands of adherents, rigidly and ruthlessly disciplined. ... [I]t seeks converts far and wide by an extensive system of schooling and indoctrination.... [Congress must pass] legislation recognizing the existence of such world-wide conspiracy and designed to prevent it from accomplishing its purpose in the United States.

The twenty-first century's "global jihad movement"132 follows the notion of a world-wide communist conspiracy in form and function. It refers to an alleged international conspiracy to organize and execute Islam-related terror attacks. ${ }^{133}$ Whenever someone is accused of such terror activity, the government claims he is part of that conspiracy. This argument, and its conceptual difficulty, is illustrated in the testimony of a government expert in United States $v$. Kassir:

[A]l Qaeda is not just an organization. Al Qaeda also views itself as an ideology. It hopes to encourage people around the world who are unable to travel to places like Afghanistan or Somalia or wherever else, it hopes to encourage those people to do what they can at home.

Particularly after 9/11, there was a tremendous emphasis on the training camps are closed [sic]. You can't just come to Afghanistan now to get training and go home. Now the battle is in your own backyard. The battle is what you yourself are able to do with your own abilities, so you should do whatever you can. It is an individual duty upon you to participate in the struggle. It is not about Usama Bin Laden and it's not about al Qaeda. It is about the methodology and the ideology behind them. If you follow the same methodology and the same ideology, then you too can be al Qaeda. ${ }^{134}$

Ironically, the United States' success against al Qaeda may contribute to this conceptually problematic approach. As the United States and its allies have been successful in targeting and disrupting al Qaeda, ${ }^{135}$ the terrorist

131 Communist Party of the U.S. v. Subversive Activities Control Bd., 367 U.S. 1, 7-8 (1961) (quotation marks omitted); see also Barenblatt v. United States, 360 U.S. 109, 131-32 (1959) ("The record discloses considerable testimony concerning the foreign domination and revolutionary purposes and efforts of the Communist Party.").

132 Robert M. Chesney, Terrorism, Criminal Prosecution, and the Preventive Detention Debate, $50 \mathrm{~S}$. TEX. L. Rev. 669, 677 (2009) [hereinafter Chesney, Terrorism, Criminal Prosecution, and the Preventive Detention Debate].

133 Although it is true that the global jihad movement is, in fact, a loosely connected international conglomeration of individuals and groups, see MARC SAGEMAN, LEADERLESS JiHAD: TERROR NETWORKS IN THE TWENTY-FIRST CENTURY (2008), I contend that it is not a combination that traditional conspiracy law recognizes.

134 United States v. Kassir, No. 04 Cr. 356 (JFK), 2009 WL 2913651, at *3 (S.D.N.Y. Sept. 11, 2009).

135 U.S. believes it can now destroy al Qaeda, REUTERs (May 3, 2011), http://www.reuters.com/article/2011/05/03/us-binladen-usa-brennanidUSTRE7422WK20110503. 
organization has been defeated as a structured organization ${ }^{136}$ that traditional conspiracy law recognizes. It has become an idea, ${ }^{137}$ and al Qaeda-inspired jihad has retained currency. ${ }^{138}$ The United States is now fighting a dangerous idea. ${ }^{139}$ This idea, much like that of communism, is the link between domestic conspiracy defendants and their supposed ideological leaders abroad. ${ }^{140}$

A defendant's alleged inclusion in the global jihad movement permits a broad swath of speech to be introduced in evidence. Someone's comment that 9/11 was justified, or that bin Laden is a role model, becomes an agreement to join the international conspiracy. Communication of this comment to another amounts to recruitment and thus an overt act. Finally, support for $9 / 11$ and bin Laden provides evidence of the mens rea to provide material support to terrorism. ${ }^{141}$

136 See Elisabeth Bumiller, New Pentagon Chief Says Qaeda Defeat in Reach, N.Y. TIMES, July 10, 2011, at A11 (reporting Defense Secretary Panetta's comments about the near-defeat of Al Qaeda and the narrowing of the U.S. campaign against the organization).

137 See Mark Mazzetti, Al Qaeda Affiliates Growing Independent, N.Y. Times, Aug. 30, 2011, at A8.

138 Jack Healy, Blasts Rock Baghdad as Political Crisis in Iraq Deepens, N.Y. TIMES, Dec. 22, 2011, http://www.nytimes.com/2011/12/23/world/middleeast/explosions-rock-baghdadamid-iraqi-political-crisis.html?_r=0.

139 See NAT'L SECURITy PREPAREDNESS GRP., Bipartisan Pol'y Center, TENTH ANNIVERSARY RePORT CARD: The Status of the 9/11 Commission Recommendations 7, 20 (Sept. 2011), available at http://www.bipartisanpolicy.org/sites/default/files/ CommissionRecommendations.pdf (warning of the continuing threats of "diversification," recruitment, and self-radicalization of violent Islamist extremism).

140 See Government's Opposition to Defendant's Motion to Dismiss Portions of Counts One through Three of the Second Superseding Indictment, United States v. Mehanna, No. 0910017-GAO, 2011 WL 3511226 (D. Mass 2011) ("Whether the [terrorist organization] ever knew that the defendants agreed to support them through [advocacy by speech] is irrelevant in a conspiracy analysis; what matters is the intent and understanding of the conspirators."); United States v. Kassir, No. 04 CR. 356 (JFK), 2009 WL 2913651, at *1, *9 n.7, (S.D.N.Y. Sept. 11, 2009) (assuming that defendant's "sharing al Qaeda's ideology" merely coincidentally was sanctioned by al Qaeda, the material support statute "can criminalize the distribution of certain written materials," which includes "jihad propaganda"); United States v. Amawi, 552 F. Supp. 2d 669, 671 (N.D. Ohio 2008) (charging defendants with conspiracy to provide material support to terrorism by distributing "how to" videos and obtaining videos from the internet even though " $[t]$ he government [did] not allege that any organized terrorist or insurgent organization solicited the defendants to commit the crimes charged to them").

141 Although beyond the scope of this Article, the global jihad movement allows statements of far-flung people to be admitted in evidence as co-conspirator statements. See FED. R. EVID. 801(d)(2)(E) (permitting at trial testimony regarding the statements of a coconspirator). Bin Laden's fatwa to kill all Americans and Jews could therefore be admissible against "homegrown terrorists." Al Qaeda's Second Fatwa, PBS NEwSHOUR (Feb. 23, 1998), http://www.pbs.org/newshour/terrorism/international/fatwa_1998.html. See United States v. Jayyousi, 657 F.3d 1085, 1099 (11th Cir. 2011); United States v. Farhane, 634 F.3d 127, 132 n.4 (2d Cir. 2011). 


\section{F. Law Enforcement Responses}

Conspiracy law is a natural response to perceived national crises because, as Justice Jackson wrote, "[c] onspiratorial movements do indeed lie back of the political assassination, the coup d'etat, the putsch, the revolution, and seizures of power in modern times ...."142 Three specific law enforcement responses to such perceived crises increase conspiracy's threat to free speech.

First, the judicial system provides for "exceptions" 143 in the context of terrorism, ${ }^{144}$ socialism, ${ }^{145}$ communism, ${ }^{146}$ and drugs, ${ }^{147}$ which create matrices of new legal rules that shift the adversarial balance in criminal cases in favor of the government and away from defendants. ${ }^{148}$ These exceptions are often viewed as necessary in light of the country's Wars on Terrorism,

142 Krulewitch v. United States, 336 U.S. 440, 448 (1949) (Jackson, J., concurring).

143 These exceptions are referred to as "the exemption of certain categories of crime from normal legal rules and a fervent hostility to any arguments challenging the underlying rationale for special treatment...." Luna, supra note 78, at 102.

144 Laurie R. Blank, The Consequences of a "War" Paradigm for Counterterrorism: What Impact on Basic Rights and Values?, 46 GA. L. ReV. 719 (2012) (arguing that the War on Terror upends delicate legal balances and thus threatens individual rights).

145 Abrams v. United States, 250 U.S. 616, 623 (1919); Frohwerk v. United States, 249 U.S. 204 (1919); Schenck v. United States, 249 U.S. 47 (1919).

146 Yates v. United States, 354 U.S. 298 (1957); Dennis v. United States, 341 U.S. 494 (1951).

147 California v. Acevedo, 500 U.S. 565, 601 (1991) (Stevens, J., dissenting); Skinner v. Ry. Labor Execs.' Ass'n, 489 U.S. 602, 641 (1989) (Marshall, J., dissenting); Nat'l Treasury Emps. Union v. Von Raab, 489 U.S. 656, 686-87 (1989) (Scalia, J., dissenting); Haneefah A. Jackson, Note, When Love is a Crime: Why the Drug Prosecutions and Punishments of Female Non-Conspirators Cannot Be Justified By Retributive Principles, 46 How. L.J. 517, 527 (2003) ("While American criminal law is firmly based on the theory that a defendant must demonstrate the requisite mens rea (the intent to commit a crime) and actus reus (the actual criminal conduct), conspiracy law provides an exception to the act requirement of criminal prosecutions. Critics of conspiracy laws argue that it violates the very foundation of our criminal justice system because it is predominately mental and rises to the level of punishing an individual for thoughts rather than acts." (footnotes omitted)); Steven Wisotsky, Crackdown: The Emerging "Drug Exception" to the Bill of Rights, 38 HASTINGS L.J. 889 (1987)

148 David B. Kopel \& Joseph Olson, Preventing a Reign of Terror: Civil Liberties Implications of Terrorism Legislation, 21 OKLA. CiTy U. L. Rev. 247, 268-69 (1996); Luna, supra note 78, at 137. One way for the drug and terrorism exceptions to operate is to not require proof of an overt act. See 18 U.S.C. $§ 2339 B$ (2006); United States v. Shabani, 513 U.S. 10, 11 (1994); United States v. Pumphrey, 831 F.2d 307 (D.C. Cir. 1987); United States v. Abdi, 498 F. Supp. 2d 1048, 1064 (S.D. Ohio 2007). 
Communism, and Drugs, ${ }^{149}$ in which the danger is apparently so serious that the government must be given great leeway in the criminal justice process. ${ }^{150}$

Second, the government applies a "prevention paradigm" of law enforcement, ${ }^{151}$ which means that inchoate offenses will be charged at ever earlier stages, ${ }^{152}$ increasing the risk of prosecutorial error. ${ }^{153}$ Because conspiracy is often proved in large part by speech, earlier law enforcement intervention also increases the risk that protected speech will be used to prove nonexistent conspiracies. ${ }^{154}$ This is, in part, why Aziz Huq has argued that the use of religious speech in terrorism trials is problematic because it is a poor signal for criminal intent in general, ${ }^{155}$ and unjustifiably targets the Muslim community specifically. ${ }^{156}$ This is a problem because it chills individuals' speech and hinders Muslim communities' ability to worship and discuss their religion. ${ }^{157}$ For example, prior to the use of religious speech as a signal of terrorism, a Muslim may have referred to himself as Salafi, which is a fundamentalist strain of Islam that is not necessarily connected to terrorism. The government has, however, connected Salafism to terrorism, so the Muslim might no longer call himself Salafi. ${ }^{158}$ Religious speech, Huq

149 Raj Dhanasekaran, When Rotten Apples Return: How the Posse Comitatus Act of 1878 Can Deter Domestic Law Enforcement Authorities From Using Military Interrogation Techniques on Civilians, 5 Conn. Pub. Interest L.J. 233, 233-38 (2005); Linda McKay-Panos, Post 9/11 Legislation and Policy in Canada-Neo-McCarthyism?, 54 U. NEW BRUNSWICK L.J. 178, 180 (2005).

150 Jules Lobel, Preventive Detention: Prisoners, Suspected Terrorists and Permanent Emergency, 25 T. JefFerson L. Rev. 389, 397 (2003); Karl T. Muth, Sarbanes-Oxley Writ Large: SarbanesOxley and the Foreign Commerce Clause, 8 J. INT'L Bus. \& L. 29, 41 (2009).

151 Robert M. Chesney, The Sleeper Scenario: Terrorism-Support Laws and the Demands of Prevention, 42 Harv. J. ON LegIS. 1, 26-30 (2005); Alberto Gonzales, U.S. Att'y Gen., Remarks at the World Affairs Council of Pittsburgh on Stopping Terrorists Before They Strike: The Justice Department's Power of Prevention (Aug. 16, 2006), available at http:// www.usdoj.gov/ag/speeches/2006/ag_speech_060816.html (calling the prevention of terrorism "a meaningful and daily triumph").

152 EMERSON, supra note 4, at 402-03 ("[T] he issues [involving the interaction between inchoate crimes and the First Amendment] are gradually beginning to emerge as the increasingly complex controls of modern society range further into inchoate conduct in the effort to punish or prevent ultimate action." (footnote omitted)).

153 See Jeremy M. Miller, RICO and the Bill of Rights: An Essay on a Crumbling Utopian Ideal, 104 CoM. L.J. 336, 345 n.40 (1999).

154 EMERSON, supra note 4, at 402 ("Inchoate conduct frequently takes the form of expression.... Consequently social regulations that reach back into inchoate conduct may raise serious First Amendment problems.”).

155 Huq, supra note 9.

$156 I d$. at 836.

157 Id. at 852; Dawinder S. Sidhu, The Chilling Effect of Government Surveillance Programs on The Use of the Internet by Muslim-Americans, 7 MD. L.J. RACE, RELIGION, GENDER \& Class 375, 376 (2007).

158 Huq, supra note 9, at 855; see also EMERSON, supra note 4, at 411 ("In practice, conspiracy law can be even more harmful to uninhibited expression. A jury, which may be hostile to an unpopular cause, decides who is in the conspiracy, what the intent of the parties was, whether the agreement contemplated some action that occurred later, and similar crucial 
argues, is inaccurately used as a proxy for criminal intent, probably underlies a number of plea bargains, ${ }^{159}$ and leads to pretextual charges such as those for false statements and immigration violations. ${ }^{160}$

Third, the government applies an "unaffiliated model" of conspiratorial liability, linking unconnected people in ways which traditional conspiracy law does not recognize. ${ }^{161}$

In the post- $9 / 11$ era, these law enforcement responses have resulted in prosecutors employing "an aggressive approach to traditional conspiracy liability, thereby establishing a capacity to prosecute potential terrorists... even in the absence of any specificity as to particular violent acts they might commit." ${ }^{\prime 162}$ The government does so by linking defendants to the "global jihad movement," unconnected to any designated foreign terrorist organization. ${ }^{164}$

These law enforcement responses carry with them the public safety virtues that traditional conspiracy law and scholars like Robert Chesney, ${ }^{165}$ Neal Kumar Katyal, ${ }^{166}$ and Lawrence Rosenthal ${ }^{167}$ express. The vice,

matters. It thus becomes dangerous for any individual to participate in a campaign or demonstration that in the course of its unfolding may give rise to some violation of law. It is hard to conceive of a more chilling effect upon the system of free expression.").

159 Huq, supra note 9, at 845 ("[M] any terrorism investigations (perhaps a majority) end in 'pretextual' charges, from wire fraud to immigration crimes. . . . In those cases, the state's upstream reliance on religious speech for singling out a suspect is never revealed." (footnote omitted)).

$160 \quad$ Id. at 847.

161 Robert M. Chesney, Beyond Conspiracy? Anticipatory Prosecution and the Challenge of Unaffiliated Terrorism, 80 S. CAL. L. REv. 425, 439 (2007) [hereinafter Chesney, Beyond Conspiracy?].

162 Chesney, Terrorism, Criminal Prosecution, and the Preventive Detention Debate, supra note 132, at $676-77$.

163 Id. at 677

164 See United States v. Kassir, No. 04 CR. 356(JFK), 2009 WL 2913651, at *3 (S.D.N.Y. Sept. 11, 2009) (describing the testimony of the government's expert that, despite having no actual connection to al Qaeda, "[i]f you follow the same methodology and the same ideology, then you too can be al Qaeda"); Government's Opposition to Defendant's Motion to Dismiss Portions of Counts One Through Three of the Second Superseding Indictment at 20, United States v. Mehanna, No. 09-10017-GAO (D. Mass. July 29, 2011) ("Whether the [foreign terrorist organization] ever knew that the defendants agreed to support them through [speaking] is irrelevant in a conspiracy analysis."); United States v. Amawi, 552 F. Supp. 2d 669, 671 (N.D. Ohio 2008) (charging defendants with conspiracy to provide material support to terrorism by distributing "how to" videos and obtaining videos from the internet even though "[t]he government [did] not allege that any organized terrorist or insurgent organization solicited the defendants to commit the crimes charged to them").

165 See Chesney, Terrorism, Criminal Prosecution, and the Preventive Detention Debate, supra note 132, at 684 (discussing conspiracy law's "capacity for prevention").

166 See Katyal, supra note 1, at 1397 (arguing that applying insights from corporate law scholars and organizational theorists to conspiracy law can stymie criminal conspiracies). 
however, is that it worsens the problems associated with the All-Purpose Speech Model by leading to the prosecution of people who may not have actually conspired to commit a crime or who were not serious about it. Some defendants may have plans that are, according to former FBI Deputy Director John Pistole, "more aspirational than operational." ${ }^{, 168}$ Others may not be criminals, but law-abiding dissenters. For those people, the prevention paradigm results in a risk of "prosecuting dissenting thought uncoupled from culpable action." It "might strike the wrong balance between the benefits of preventive action and the risks that defendants will be prosecuted for acts that they might never actually have committed." The All-Purpose Speech Model lies at the heart of this "wrong balance."

\section{THE INTERSECTION OF SPEECH AND CONSPIRACY}

By now it is clear that speech intersects with conspiracy in intimate and important ways. Questions remain: When is this intersection not a problem? Why do problems arise? What is the structure of the problem? And what is the danger flowing from this problem?

\section{A. When the All-Purpose Speech Model Presents No Problem}

The All-Purpose Speech Model observes that speech can be both a crime and evidence thereof. If nothing else is said, this observation does not amount to much. We are normatively satisfied with many categories of speech being crimes (and thus unprotected), ${ }^{171}$ just as we are with relevant speech being admissible as evidence of crimes (thus, in my controversial

167 See Rosenthal, supra note 9, at 117 (arguing that "statements of ideological belief may provide valuable evidence of motive or intent in criminal prosecutions").

168 Chesney, supra note 132, at 685 (quoting Transcript, Attorney General Gonzales Holds a News Conference on Terrorist Arrests, WASH. POsT (June 23, 2006), http://www.washingtonpost.com/wpdyn/content/article/2006/06/23/AR200606230094 2.html.).

169 Chesney, Beyond Conspiracy?, supra note 161, at 426 (describing the position of civil liberties advocates).

170 Id. at 435 (citing Dahlia Lithwick, Stop Me Before I Think Again, WASH. Post, July 16, 2006, at B3).

171 These include, for example, true threats, incitement, false statements, and fraud. 
opinion, ${ }^{172}$ unprotected $^{173}$ ). In run-of-the-mill cases, speech and crime intersect in two justifiable ways. ${ }^{174}$

First, consider a defendant who is charged with conspiracy in connection with a planned bank robbery who is caught by law enforcement with a shotgun in the process of executing the robbery. ${ }^{175}$ The admission in evidence of the defendant's writings that referred to committing crimes with shotguns $^{176}$ is not a problem, even in light of the defendant's First Amendment objection that the writings show only his abstract beliefs. ${ }^{177}$ This is so because when actual conduct occurs, the outcome reliability concerns inherent in using speech as evidence of a speech crime are largely absent. In other words, the conduct of possessing the gun lends great relevancy to the speech. When actual conduct takes place, the All-Purpose Speech Model poses no real problem.

Second, a defendant accused of selling drugs might have explicitly discussed with co-conspirators the amount of drugs involved in their crime. ${ }^{178}$ Admission of these discussions is also not a concern, even if no drugs are found. This case does not present serious All-Purpose Speech Model concerns because the speech is unambiguously associated with legitimately criminal activity. ${ }^{179}$

The First Circuit's approach in the landmark conspiracy case, United States v. Spock, refers to both of these occasions. Limiting the use of speech to prove mens rea, the Court wrote:

When the alleged agreement is both bifarious and political within the shadow of the First Amendment, we hold that an individual's specific intent to adhere to the illegal portions may be shown in one of three ways: by the individual defendant's prior or subsequent unambiguous statements; by the individual defendant's subsequent commission of the very illegal act contemplated by the agreement; or by the individual

172 See Greenawalt, Speech, Crime, and The Uses of Language, supra note 5, at 245 ("[F]reedom to say what one feels and believes and hopes to do does not constitute freedom from use of one's statements as evidence.").

173 Thomas I. Emerson, however, shared this opinion. EMERSON, supra note 4, at 405 (" $[E]$ xpression may be seriously inhibited when the speaker knows that what he says can be used against him at a later time ... or can perhaps be the decisive factor in a jury's general verdict against him.”).

174 See United States v. Spock, 416 F.2d 165, 185 \& n.2 (1st Cir. 1969) (Coffin, J., dissenting in part) (citing Direct Sales Co. v. United States, 319 U.S. 703 (1943)) (“[T]here is ... justification... [for] fearing expansion of conspiracy into the realm of public discussion.... Of course, closely-knit groups directed at the execution of orthodox criminal enterprises are clearly punishable as conspiracies.").

175 United States v. Brown, 374 Fed. App’x 927, 930 (11th Cir. 2011).

176 Id. at $930,937$.

$177 \quad$ Id. at 937.

178 United States v. Padilla-Gonzalez, 418 Fed. App'x 590, 592 (9th Cir. 2011).

179 In Part IV of this Article, I discuss such speech as operational and integral to criminal conduct. 
defendant's subsequent legal act if that act is "clearly undertaken for the specific purpose of rendering effective the later illegal activity which is advocated."

\section{B. Why Do Problems Arise?}

The pursuit of all inchoate crimes poses an inherent danger of erroneous outcomes. ${ }^{181}$ Expanded use of the prevention paradigm, unaffiliated model, and specific crime exceptions all encourage law enforcement intervention at ever earlier points in time. While this may serve public safety, it also intensifies problems associated with the AllPurpose Speech Model. Invoking these problems, Eugene Volokh asked:

Would you feel safe writing an article describing how easily people can illegally make [a] drug, and using that as an argument for why it's pointless to keep the drug illegal, when you know that your past praise of the drug might persuade a jury that the article is really intended to facilitate crime?

Volokh pointed to the problematic use of speech when there is no actual conduct to vouch for its reliability or when the speech used is dubiously probative of criminal intent or agreement.

Courts have failed to address this problem because they have focused only on speech-as-crime. Contrary to the holdings in a prominent line of cases, ${ }^{183}$ conspiracy charges largely do away with defendants' speech rights

180 United States v. Spock, 416 F.2d 165, 173 (1st Cir. 1969) (quoting Scales v. United States, 367 U.S. 203, 234 (1961)) (emphasis added).

181 See Larry Alexander \& Kimberly D. Kessler, Mens Rea and Inchoate Crimes, 87 J. CRIM. L. \& Criminology 1138, 1173 (1997) (“[A]lthough the Model Penal Code's approach to conditional purpose is the most defensible approach, it leads to counter-intuitive results in many cases.").

182 See Volokh, Crime-Facilitating Speech, supra note 10, at 1189.

183 Some have said that Dennis v. United States established that the First Amendment protects some speech in the conspiracy context. In the context of this Article, Dennis is appropriately viewed as a traditionalist First Amendment case in that it is concerned solely with speech itself as a crime. In that context, the Court wrote that, "where an offense is specified by a statute in nonspeech or nonpress terms, a conviction relying upon speech or press as evidence of violation may be sustained only when the speech or publication created a 'clear and present danger' of attempting or accomplishing the prohibited crime, e.g., interference with enlistment.” 341 U.S. 494, 505 (1951). The Dennis majority concerned itself with speech as a crime and did not appreciate the allpurpose speech problem presented in this Article. Justices Black and Douglas in dissent, however, did point to this Article's concern. Id. at 579, 585 (Black, Douglas, JJ., dissenting). A decade later, the Court reiterated the Dennis approach in Scales v. United States, writing that:

$[\mathrm{T}]$ here is no great difference between a charge of being a member in a group which engages in criminal conduct and being a member of a large conspiracy, many of whose participants are unknown or not before the court. Whatever difficulties might be thought to inhere in ascribing a course of criminal conduct to an abstract entity are certainly cured, so far as any particular defendant is 
altogether, in part because those cases do not recognize the dual nature of the All-Purpose Speech Model. Thus, when the First Circuit in Spock said, "the important lesson of Noto, Scales and Yates [is] that one may belong to a group, knowing of its illegal aspects, and still not be found to adhere thereto," ${ }^{184}$ it was expressing a normative hope, resting on a presumed, but largely inoperative, balancing test. ${ }^{185}$ Membership in such groups cannot itself be criminal, but it can be used as evidence of conspiracy, which in turn establishes the crime itself.

\section{Structure of the Problem}

\section{Agreement}

An agreement to commit a crime lies at the heart of conspiracy law. ${ }^{186}$ It is a necessary actus reus ${ }^{187}$ and can also indicate the mens rea of the conspirators. ${ }^{188}$ At first blush, the fact that the agreement can perform this dual role is not a conceptual concern: an agreement to commit a crime is surely evidence of someone's criminal state of mind. There are other characteristics, however, that raise All-Purpose Speech Model issues.

Circumstantial evidence is admissible to prove an agreement. ${ }^{189}$ There need not be an explicit offer and acceptance to engage in a criminal

concerned, by the requirement of proof that he knew that the organization engages in criminal advocacy, and that it was his purpose to further that criminal advocacy.

367 U.S. at 226 n.18. The Court's concern was merely to ensure that criminal intent was proven; it did not confront the all-purpose speech problem or even greatly question the ambiguous nature of some speech to prove intent. In the same year, however, the Court in Noto $v$. United States did suggest an appreciation of the all-purpose speech problem. 367 U.S. 290, 298 (1961) ("But in examining that evidence it appears to us that, in the context of this record, this too fails to establish that the Communist Party was an organization which presently advocated violent overthrow of the Government now or in the future, for that is what must be proven. The most that can be said is that the evidence as to that program might justify an inference that the leadership of the Party was preparing the way for a situation in which future acts of sabotage might be facilitated, but there is no evidence that such acts of sabotage were presently advocated; and it is present advocacy, and not an intent to advocate in the future or a conspiracy to advocate in the future once a groundwork has been laid, which is an element of the crime under the membership clause.").

184416 F.2d at 179.

185 Id. at 170.

186 Ianelli v. United States, 420 U.S. 770, 777 (1975); Braverman v. United States, 317 U.S. 49, 53 (1942); Mendocino Envtl. Ctr. v. Mendocino Cnty., 192 F.3d 1283, 1301 (9th Cir. 1999); United States v. Roberts, 14 F.3d 502, 511 (10th Cir. 1993).

187 United States v. Shabani, 513 U.S. 10, 16 (1994) (citing Regina v. Bass, (1795) 88 Eng. Rep. 881, 882).

188 Ohlin, supra note 15.

189 Bell Atlantic Corp. v. Twombly, 550 U.S. 544, 553 (2007); Theatre Enters., Inc. v. Paramount Film Distrib. Corp., 346 U.S. 537, 540 (1954). 
conspiracy; the agreement may be inferred from evidence of concert of action among people who work together to achieve a common end. ${ }^{190} \mathrm{~A}$ tacit understanding may be sufficient, ${ }^{191}$ as may be "the working relationship between the parties that has never been articulated but nevertheless amount to a joint criminal enterprise." 192

As Abraham Goldstein wrote, "[t]he illusory quality of agreement is increased by the fact that it, like intent, must inevitably be based upon assumptions about what people acting in certain ways must have had in mind." ${ }^{193}$ Although mere presence, guilty knowledge, and even close association with an alleged co-conspirator are insufficient on their own to prove a conspiracy, ${ }^{194}$ they may be considered to raise a permissible inference of participation in a conspiracy. ${ }^{195}$ By piling on evidence of "bad" speech and associations, prosecutors can paint a picture of a conspiracy where in reality there is none. ${ }^{196}$

This presents difficulties for juries. How can juries determine what is an agreement and what is mere presence or close association? Assuming jurors are able to do so, how are they to process the apparent contradiction that presence or association cannot be used alone to prove an agreement, but may be used to infer participation in the conspiracy? These problems are exacerbated by the fact that conspiracy is believed to be characterized by secrecy and is therefore usually difficult to prove except by inferences drawn from the conduct of the parties. ${ }^{197}$

The practical results of these problems are twofold. First, prosecutors will introduce as massive an amount of evidence as possible in the hope that more evidence of presence, knowledge, and association will inundate

190 American Tobacco Co. v. United States, 328 U.S. 781, 809-10 (1946); United States v. Hegwood, 977 F.2d 492, 497 (9th Cir. 1992) (citing United States v. Disla, 805 F.2d 1340, 1348 (9th Cir. 1986)); United States v. Lopez, 979 F.2d 1024, 1029 (5th Cir. 1992); United States v. Simon, 839 F.2d 1461, 1469 (11th Cir. 1988); WRIGHT, supra note 12.

191 United States v. Paramount Pictures, 334 U.S. 131, 142 (1948); United States v. Concemi, 957 F.2d 942 (1st Cir. 1992) (citing United States v. Boylan, 898 F.2d 230, 241-42 (1st Cir. 1990)); United States v. Rea, 958 F.2d 1206, 1214 (2d Cir. 1992).

192 United States v. Wiener, 3 F.3d 17, 21 (1st Cir. 1993); see also United States v. Townsend, 924 F.2d 1385 (7th Cir. 1991).

193 Goldstein, supra note 1, at 410.

194 United States v. Lyons, 53 F.3d 1198, 1201 (11th Cir. 1995).

195 United States v. Hernandez, 896 F.2d 513, 518 (11th Cir. 1990) (quoting United States v. Kincade, 714 F.2d 1064, 1065 (11th Cir. 1983)).

196 There has, in fact, been confusion about what agreement conceptually entails. See Theodore W. Cousens, Agreement as an Element in Conspiracy, 23 VA. L. REV. 898, 909 (1937) (discussing "confusion" regarding agreement in federal courts).

197 United States v. Muse, No. 06 Cr. 600(DLC), 2007 WL 1989313, at* 4 (S.D.N.Y. July 3, 2007); United States v. Ailsworth, 948 F. Supp. 1485, 1506 (D. Kan. 1996); JosEPH F. McSorley, A Portable Guide to Federal Conspiracy law: TACTICS and Strategies FOR CRIMINAL AND CIVIL CASES 12-13 (2d ed. 2003). 
jurors ${ }^{198}$ and compel them to find an agreement. ${ }^{199}$ This rests on an a priori assumption that a conspiracy exists. "The trial becomes a vehicle for constant shaping and forming of the crime, through colloquies among court and counsel, as each new item of evidence is offered by the prosecution to fill out an agreement whose scope will be unknown until the entire process is completed." ${ }^{200}$ Second, given the apparent difficulty in proving conspiracies because of their secrecy, courts relax standards of proof in favor of the prosecution in ways that affect the relevance inquiry for determining admissibility of evidence. ${ }^{201}$ The fact that co-conspirator hearsay is admissible facilitates these processes. ${ }^{202}$ If there are terrorism ${ }^{203}$ and drug

198 See Note, Conspiracy and the First Amendment, supra note 1, at 878 (warning that "the volume of evidence produced by a trial of several defendants may overwhelm the jury").

199 See United States v. Dellosantos, 649 F.3d 109 (1st Cir. 2011) (describing how a jury was confused by "the plethora of evidence implicating the other sixteen indicted codefendants"); EMERSON, supra note 4, at 410 ("[T] he wide sweep of a conspiracy charge, and the multiplicity of participants, make it possible for the prosecution to claim that broad areas of expression are relevant to the case.").

200 Goldstein, supra note 1, at 412.

201 See Blumenthal v. United States, 332 U.S. 539, 556-57 (1947) ("Secrecy and concealment are essential features of a successful conspiracy.... Hence the law rightly gives room for allowing the conviction of those discovered upon showing sufficiently the essential nature of the plan and their connections with it, without requiring evidence of knowledge of all its details or of the participation of others."); United States v. Brodie, 403 F.3d 123, 134 (3d Cir. 2005) (citing Blumenthal, 332 U.S. at 557) ("[T]he very nature of the crime of conspiracy is such that it often may be established only by indirect and circumstantial evidence. Thus, " $[t]$ he existence of a conspiracy "can be inferred from evidence of related facts and circumstances from which it appears as a reasonable and logical inference, that the activities of the participants ... could not have been carried on except as the result of a preconceived scheme or common understanding."'” (citation omitted)); United States v. Dazey, 403 F.3d 1147, 1159 (10th Cir. 2005) ("Because '[s]ecrecy and concealment are essential features of successful conspiracy,' direct evidence of conspiracy is often hard to come by. Therefore, conspiracy convictions may be based on circumstantial evidence, and the jury may infer conspiracy from the defendants' conduct and other circumstantial evidence indicating coordination and concert of action." (citations omitted)).

202 FED. R. EVID. 801(d) (2) (E).

203 Blank, supra note 144, at 740-41 (arguing that the War on Terror upends delicate legal balances and thus threatens individual rights). 
exceptions, $^{204}$ they compound what can be called the "conspiracy exception." 205

The agreement is the lynchpin element in conspiracy cases. This could have led courts either to make it more or less difficult to prove. Given the widely held belief that conspiracies are difficult to prove, courts have given the prosecution great advantages in proving an agreement. ${ }^{206}$ This means that the agreement element does not pose a significant barrier to a conspiracy charge, and it is difficult for the defendant to disprove whenever multi-person inchoate activity is implicated in the criminal process.

\section{Overt Act}

In addition to an agreement, proof of a conspiracy usually requires an overt act. $^{207}$ Its primary purpose is to show the operation of the conspiracy. ${ }^{208}$ Put another way, the requirement of an overt act represents an acknowledgement that talk (the agreement) is cheap. A second purpose of

204 See California v. Acevedo, 500 U.S. 565, 601 (1991) (Stevens, J., dissenting) (arguing that the Court has become a "loyal foot soldier" in the war on drugs); Skinner v. Ry. Labor Execs.' Ass'n, 489 U.S. 602, 641 (1989) (Marshall, J., dissenting) (criticizing the majority opinion as incorporating a "drug exception" into the Constitution); Nat'l Treasury Emps. Union v. Von Raab, 489 U.S. 656, 686-87 (1989) (Scalia, J., dissenting) (arguing that the "war on drugs" does not provide sufficient justification for an invasion of privacy); Wisotsky, supra note 147, at 890 (arguing that Constitutional protections have been eroded by the war on drugs).

205 See, e.g., Dennis v. United States, 341 U.S. 494, 568-69 (1951) (Jackson, J., concurring) (rejecting the clear and present danger test when a criminal charge involves "a wellorganized, nationwide conspiracy").

206 See EMERSON, supra note 4, at 409 ("[T] he use of conspiracy prosecution relaxes the ordinary rules of evidence... and usually affords the prosecuting officials other significant advantages."); Note, Conspiracy and the First Amendment, supra note 1, at 877-78 (" $[\mathrm{O}] \mathrm{n}$ the theory that conspiratorial agreements are secret and hence seldom susceptible to direct proof, courts relax the normal rules of evidence." (footnote omitted)).

207 This is not always the case. In Title 21 drug conspiracy prosecutions, for example, the state need not prove that the defendant committed an overt act. United States v. Shabani, 513 U.S. 10, 11 (1994); United States v. Pumphrey, 831 F.2d 307, 308 (D.C. Cir. 1987). Some conspiracies to provide material support to a foreign terrorist organization do not have an overt act requirment either. See 18 U.S.C. § 2339B (2006); United States v. Abdi, 498 F. Supp. 2d 1048, 1064 (S.D. Ohio 2007) ("In drafting section § 2339B, Congress omitted any language requiring an overt act."). Nor do conspiracies to commit money laundering. See Whitfield v. United States, 543 U.S. 209, 211 (2005) (holding that conviction for conspiracy to commit money laundering does not require a showing of an overt act).

208 See United States v. Medina, 761 F.2d 12, 15 (1st Cir. 1985) (citing Yates v. United States, 354 U.S. 298, 334) (explaining the function of the overt act requirement is to "show the operation of the conspiracy"). 
the overt act is to provide a locus pænitentice, or a chance for a conspirator to withdraw from the conspiracy without accruing any liability. ${ }^{209}$

The overt act requirement is intended to limit the definition of conspiracies and ensure that only people who have actually conspired are indicted. The requirement should, for example, prevent mere braggarts from being prosecuted for "agreeing" to rob a bank or kill a political figure with whom they particularly disagree. In fact, it is so easy to prove an overt act that the element has little meaning at all.

The overt act need not be illegal in and of itself. It can be a very minor act, including making a phone call, ${ }^{210}$ traveling to another city, ${ }^{211}$ watching a video, ${ }^{212}$ sending a text message, ${ }^{213}$ or giving or receiving directions. ${ }^{214}$ Almost anything that the prosecution can show furthered the alleged conspiracy in any way will be admitted in evidence. Because the overt act can be something very minor, its role as a locus pæenitentice is not a strong one; if the government wants to prosecute someone, it can easily find an overt act to charge. ${ }^{215}$

Having found an overt act, jurors may use it to infer an agreement. ${ }^{216}$ This is circular logic that collapses the separate actus rei of agreement and overt act into one. For example, we know that defendants agreed to rob a

209 See United States v. Olmstead, 5 F.2d 712, 714 (W.D. Wash. 1925) ("The purpose of the overt act is to afford a locus pœnitentiæ, when either or all of the conspirators may abandon the unlawful purpose.");

210 See, e.g., Bartoli v. United States, 192 F.2d 130, 132 (4th Cir. 1951) (holding that telephone conversations between defendant and co-conspirators "were all overt acts").

211 See, e.g., United States v. Scallion, 533 F.2d 903, 911 (5th Cir. 1976) (holding that "traveling to Las Vegas" was one of a set of actions that constituted an overt act).

212 See, e.g., Second Superseding Indictment at 3, 13, United States v. Mehanna, No. 09-CR10017-GAO (D. Mass. June 17, 2010) (alleging that defendants commited an overt act when they watched "jihadi videos").

213 See, e.g., United States v. Stokes, No. 10-00244-04-CR-W-DW, 2011 WL 1585601, at *5 (W.D. Mo. Apr. 25, 2011) (noting, in an order denying motion to sever defendants and granting motion to sever counts, that the prosecution alleged that "us[ing] the internet to send a text message" was an overt act).

214 See United States v. Rose, 315 F.3d 956, 958 (8th Cir. 2003) (holding that defendant "carried out overt acts in furtherance of his threats by . . finding [the victim's] address, determining its location and obtaining directions to the site); United States v. Gosselin, 62 M.J. 349, 354 (C.A.A.F. 2006) (noting that defense counsel conceded at oral argument that "giving directions" was an overt act); Kang v. Giurbino, No. CV 07-5693-AHM (RCF), 2010 WL 3834884, at *10 (C.D. Cal. July 26, 2010) (noting that the jury found defendants committed overt act when they "assaulted [the victim], threatened to kill her, threw her on the bed, bound her hands and feet, [and] forced her to give them her address and directions to her house").

215 See Note, Conspiracy and the First Amendment, supra note 1, at 878 (arguing that the overt act "requirement is seldom more than a formality").

216 See Fowler v. United States, 131 S. Ct. 2045, 2059 n.2 (2011) (Alito, J., dissenting) (" $[\mathrm{O}]$ vert acts committed in furtherance of a conspiracy may be sufficient to permit a jury to infer that a conspiratorial agreement was reached ...."). 
bank because they bought ski masks. Buying ski masks constitutes an overt act because the defendants agreed to rob the bank. This logic encourages proof by verbosity and so prosecutors will inundate the jury with massive amounts of apparently damning evidence that may not be probative. ${ }^{217}$ As actus rei are piled into evidence, the prosecutor simultaneously and effortlessly proves the mens rea, and vice versa. ${ }^{218}$

Otherwise protected speech can be used as an overt act. For example, a defendant's statement, "[t]he banking system is unjust and we need to do everything we can to undermine it," may be relevant to proving motive or intent to form a conspiracy to rob a bank. To say that this statement furthers the conspiracy, however, is often a tenuous argument, but one that courts accept. ${ }^{219}$ Other countries ${ }^{220}$ and the United States, in treason trials, prohibit the use of speech as an overt act.

\section{a. Treason}

As the only crime enumerated in the United States Constitution, and one that explicitly requires an overt act, ${ }^{221}$ treason provides an originalist vantage point for a discussion about the use of speech to prove conspiracy's elements. It suggests that the law should treat conspiracy's overt act as not only quantitatively more than some minor and legal act, but also qualitatively different than mere speech, however "bad."

Courts have held uniformly that treason's overt act must be actual conduct; it may not be speech in any form. ${ }^{222}$ This is so because the overt act

217 See United States v. Dellosantos, 649 F.3d 109, 125 (1st Cir. 2011) (holding that a jury in a conspiracy trial was unduly influenced by "a plethora of evidence" introduced by the prosecution).

218 Nathan R. Sobel, The Anticipatory Offenses in the New Penal Law: Solicitation, Conspiracy, Attempt and Facilitation, 32 BROOK. L. ReV. 257, 264 (1966) ("[P]ractical experience is convincing that the requisite mens rea is extremely difficult to establish absent an overt act which signals the intent to move the project forward from talk to action.").

219 See United States v. Elliott, 571 F.2d 880, 887 n.4 (5th Cir. 1978) (noting that words of encouragement may be an overt act).

220 France, for example, requires one or more "overt acts.” CODE PÉNAL [C. PÉN.] art. 450-1 (Fr.).

221 U.S. CONST. art. III, § 3, cl. 1 ("No Person shall be convicted of Treason unless on the Testimony of two Witnesses to the same overt Act, or on Confession in open Court.").

222 See Douglas A. Kash, The United States v. Adam Gadahn: A Case for Treason, 37 CAP. U. L. REV. 1, 23 (2008) (“[O]ne's sentiments of discontent or utterances of disloyal sentiments are not sufficient to support the charge of treason."). But see Tom W. Bell, Treason, Technology, and Freedom of Expression, 37 ARIZ. ST. L.J. 999, 1026 (2005) ("The World War II propaganda cases leave no doubt that a speech or publication can constitute an overt act sufficient to trigger punishment for treason."); Kristen Eichensehr, Treason's Return, 116 YAle L.J. POCKET PART 229, 229 (2007) (observing that 2006 prosecution of Adam Gadahan for participating in propaganda videos resembled World War II-era treason prosecutions). 
requirement exists to show that the treasonous intent has moved from the realm of thought into the realm of action. ${ }^{223}$ Held against the mirror of American treason jurisprudence, the use of speech to prove a conspiracy's overt act seems overly broad, unfaithful to stare decisis, and even unconstitutional. ${ }^{224}$

In Yates v. United States, Justice Black invoked treason to address the concerning confluence of speech rights and conspiracy trials, writing, " $[t]$ he requirement of proof of an overt act in conspiracy cases is no mere formality, particularly in prosecutions like these [anti-communist trials] which in many respects are akin to trials for treason." ${ }^{225}$ The high

223 See Haupt v. United States, 330 U.S. 631, 645 (1947) ("The requirement of an overt act is to make certain a treasonable project has moved from the realm of thought into the realm of action.”); Cramer v. United States, 325 U.S. 1, 7 n.7 (1945) (quoting United States v. Haupt, 47 F. Supp. 836, 839 (N.D. Ill. 1942) ("[A]n overt act ... means some physical action done for the purpose of carrying out or affecting [sic] the treason." (alteration in original))); United States v. Werner, 247 F. 708, 710 (E.D. Pa. 1918) (quoting Charge to Grand Jury-Treason, 30 F. Cas. 1034, 1034 (C.C.S.D.N.Y. 1861)) ("Words oral, written or printed, however treasonable, seditious or criminal of themselves, do not constitute an overt act of treason, within the definition of the crime."); Ex parte Vallandigham, 28 F. Cas. 874, 886-87 (Ohio C.C. 1863) (" $[\mathrm{H}]$ ow is it possible that words, merely as such, should 'amount' to treason? The crime requires an overt act.”).

224 Indeed, Justice Douglas questioned whether a conspiracy's overt act could be proven by constitutionally protected activity. The question has gone unanswered. See Epton v. New York, 390 U.S. 29, 31 (1968) (Douglas, J., dissenting) (noting that the Court "has never decided whether activities protected by the First Amendment can constitute overt acts for purposes of a conviction for treason"). Courts uniformly acquiesce to the assumption that when speech is used to prove a conspiracy's agreement and overt act, the First Amendment is not implicated. See, e.g., United States v. El-Mezain, 664 F.3d 467, 537 (5th Cir. 2011) (quoting Wisconsin v. Mitchell, 508 U.S. 476, 489 (1993)) ("It is well established under First Amendment principals that there is no prohibition on 'the evidentiary use of speech to establish the elements of a crime ...."')); United States v. Curtin, 489 F.3d 935, 955 (9th Cir. 2007) (holding that "reading material" evidence which would otherwise be constitutionally protected could be admitted as evidence); United States v. Berringer, 601 F. Supp. 2d 976, 978 (N.D. Ohio 2008) (holding that constitutionally protected pornographic material may be introduced as evidence); Joseph J. Anclien, Crush Videos and the Case for Criminalizing Criminal Depictions, 40 U. MEM. L. REV. 1, 10-11 (2009) (listing criminal conduct that is not protected by the First Amendment); Mark A. Behrens \& Christopher E. Appel, The Need for Rational Boundaries in Civil Conspiracy Claims, 31 N. ILL. U. L. REv. 37, 66 (2010) (arguing that criminal liability "based on relationships in associations may chill the exercise of fundamental constitutional rights, namely, freedom of expression and association" (footnote omitted)); Malick W. Ghachem, Of "Scalpels" and "Sledgehammers": Religious Liberty and the Policing of Muslim Charities in Britain and America Since 9/11, 9 UCLA J. IsLAMIC \& NEAR E. L. 25, 52 n.113 (2010) (" $[\mathrm{I}] \mathrm{n}$ certain areas of the law, such as criminal solicitation and conspiracy or securities regulation, the First Amendment is simply held not to apply.") (citing Frederick Schauer, The Boundaries of the First Amendment: A Preliminary Exploration of Constitutional Salience, 117 HARV. L. REv. 1765 (2004)); EMERSON, supra note 4, at 409 ("It can readily be seen that the law of conspiracy reaches far back into inchoate conduct and has serious implications for the system of freedom of expression." (footnote omitted)).

225354 U.S. 298, 342 (1957) (Black, J., concurring in part and dissenting in part). 
evidentiary bar set for proof of treason was necessary, he said, "to keep people from being convicted of disloyalty to government during periods of excitement when passions and prejudices ran high, merely because they expressed 'unacceptable' views. ${ }^{, 26}$

Justice Douglas revisited this observation twelve years later, writing in Epton v. New York, "[w] hether the overt act required to convict a defendant for conspiracy must be shown to be constitutionally unprotected presents an important question." ${ }^{227}$ He returned to treason: "Although the Court has indicated that the overt act requirement of the treason clause ensures that 'thoughts and attitudes alone cannot make a treason' it has never decided whether activities protected by the First Amendment can constitute overt acts for purposes of a conviction for treason." ${ }^{228}$ His question has gone unanswered. ${ }^{229}$

\section{Actus Reus and Mens Rea}

If the Framers were concerned that talk was cheap, at least in the treason context, criminal law has similarly been concerned with how to prove that someone actually meant to do the crime of which he was accused. Lord Coke developed the principle actus non facit reum nisi mens sit rea, or "an act does not make a person guilty unless [his] mind is also guilty." principle emerged the separate concepts of actus reus and mens rea.

The concepts of actus reus and mens rea are meant to perform different tasks. Actus reus is meant to ensure that an act that is prohibited actually took place. Mens rea is meant to ensure that if the act took place, the actor had a guilty state of mind. ${ }^{231}$ The two concepts have, for good reason, been conceptually separated from each other, though some have been skeptical that they are, in reality, distinct. ${ }^{232}$

Id. at 343 (citing Cramer, 325 U.S. at 48).

390 U.S. 29, 31 (1968) (Douglas, J., dissenting). See also Samuels v. Mackell, 401 U.S. 66, 75 (1971) (Douglas, J., concurring) ("There is a question concerning some of the overt acts-whether... a constitutionally protected right such as speech or assembly may be used as an overt act in furtherance of a conspiracy.").

Epton, 390 U.S. at 31 (internal citations omitted).

See Bell, supra note 222, at 1030 (noting that the Supreme Court has not decided whether protected speech can constitute an overt act).

EDWARD COKe, THE THIRD PART OF THE Institutes OF THE LAWS OF ENGLAND: Concerning High Treason, and Other Pleas of the Crown, and Criminal Causes 107 (M. Flesher et al. 1600); WAYNe R. LAFAVE, 1 Substantive Criminal LaW $\$ 5.1(\mathrm{a})$, at 333 (2d ed. 2003).

1 See People v. Torres, 848 P.2d 911, 914 (Colo. 1993) (defining mens rea as "a culpable mental state"); Garnett v. State, 632 A.2d 797, 800 (Md. 1993) (defining mens rea as "the guilty mind or mental state accompanying a forbidden act").

32 See, e.g., JEROME HALL, GENERAL PRINCIPLES Of CRIMINAL LAW 70 (2d. ed. 1960); DOUGLAS N. HusaK, Philosophy of Criminal LaW 91 (1987). 
Michael Moore rejected this skepticism, ${ }^{233}$ but acknowledged that "complex action" crimes do see a merger of actus reus and mens rea. ${ }^{234} \mathrm{He}$ noted conspiracy's complexity, ${ }^{235}$ and so his discussion of actus reus in that crime indicated its merger with the crime's mens rea. ${ }^{236}$ The All-Purpose Speech Model highlights this merger; in speech, however ambiguous, a prosecutor can find both actus reus and evidence of mens rea. ${ }^{237}$ The prevention paradigm means that the probity of speech is increasingly doubtful as government pursues potential crimes at earlier and earlier stages. This means that alleged agreements are even more inferred, and prosecutors attempt to prove them by even more ambiguous speech. Lines blur even further, and proof of actus reus and mens rea become less distinct. $^{238}$

\section{Actus Reus and Evidence Thereof}

Just as prosecutors can find both actus reus and evidence of mens rea in the same speech, they can similarly find both actus reus and evidence thereof. Al-Hussayen's website administration, for example, provided the overt act, evidence of the agreement, and evidence of his mens rea to support his conspiracy charge. This once again amounts to circular logic: we know Al-Hussayen agreed to provide material support because he engaged in an overt act in its furtherance, and we know this was an overt act because he had agreed to provide material support.

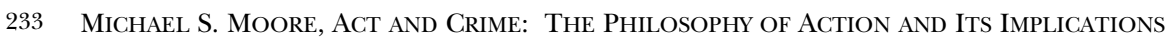
FOR CRIMINAL LAW 171-77 (1993).

$234 I d$. at 174 (noting specifically that in complex action crimes, "there is indeed a blending of the actus reus and mens rea requirements in the sense that one cannot have satisfied the actus reus requirement for such crimes without also having satisfied the mens rea requirement of such crimes").

$235 I d$. at 225.

236 Id. at 220-21.

237 See Jackson, supra note 147, at 527 ("While American criminal law is firmly based on the theory that a defendant must demonstrate the requisite mens rea (the intent to commit a crime) and actus reus (the actual criminal conduct), conspiracy law provides an exception to the act requirement of criminal prosecutions. Critics of conspiracy laws argue that it violates the very foundation of our criminal justice system because it is predominately mental and rises to the level of punishing an individual for thoughts rather than acts." (footnotes omitted)).

238 This is to say nothing of the problem of proving mens rea itself in the context an inchoate crime. See Alexander \& Kessler, supra note 181, at 1139 (noting that "[f]or an inchoate crime such as conspiracy, solicitation, or incomplete attempt" criminal codes impose a purpose requirement that is "ambiguous in two respects"). 


\section{A Structure OF SPEECH}

While conspiracy law has failed to address the problems associated with the All-Purpose Speech Model, speech law has similarly been unsuccessful. What is needed is a typology of speech that illustrates how conspiracy law threatens free speech. Two preexisting systems, the category of speech integral to criminal conduct ${ }^{239}$ and Kent Greenawalt's tripartite structure of speech, ${ }^{240}$ provide good starting points. From these structures a new fourpart typology emerges that reveals the threat and, in the future, may guide questions of admissibility based on whether the speech in question is necessary, facilitative, or merely related to a conspiracy, and whether the speech is aspirational or operational. I call this the Conspiracy Specific Speech Typology.

\section{A. Pre-Existing Structures}

\section{Speech Integral to Criminal Conduct}

Speech integral to criminal conduct (“integral speech") provides insight into the use of speech to prove a conspiracy charge. At its simplest, if speech is integral to a conspiracy, then it is not protected. ${ }^{241}$ Conversely, if speech is not integral, then it may be protected. It makes sense that speech that comprises a conspiracy's agreement or overt act is integral, and so can be prohibited. This is fine as far as its goes, which is not very far. As we will see, case law leaves us wanting an adequate definition of integral speech, especially in the conspiracy context. In addition, integral speech says nothing about speech as evidence of actus reus or mens rea.

Only a small number of cases mention the category of integral speech. ${ }^{242}$ Fittingly, only a small amount of scholarship touches on the category. ${ }^{243}$

239 EMERSON, supra note 4, at 406 ("Perhaps the best formulation that can be made . . is that there must be an unusually close connection between the expression and the action, that the expression must be an integral part of the action.").

240 Greenawalt, SPEECH, Crime, AND The Uses of LANGUAge, supra note 5, at 43, 57.

241 See United States v. Stevens, 130 S. Ct. 1577, 1599-1600 (2010) (noting that the First Amendment would not, in and of itself, be an automatic bar to statutory criminal liability for videographers engaged in a conspiracy to make live recordings to satisfy an underground market for videos of sadistic acts of animal cruelty); see also Giboney v. Empire Storage \& Ice Co., 336 U.S. 490, 498 (1949) (in the context of a case involving picketers of a commercial enterprise, noting that it "rarely has been suggested that the constitutional freedom for speech and press extends its immunity to speech or writing used as an integral part of conduct in violation of a valid criminal statute").

242 Stevens, 130 S. Ct. at 1584; United States v. Alvarez, 638 F.3d 666, 670, 671 n.4, 683 (9th Cir. 2011); Powell's Books, Inc. v. Kroger, 622 F.3d 1202, 1212 n.15 (9th Cir. 2010); United States v. White, 610 F.3d 956, 960 (7th Cir. 2010); Siefert v. Alexander, 608 F.3d 974, 991 (7th Cir. 2010); Quiney v. Brooks, 2:10-CV-01676-GMN, 2011 WL 1327856, at*3 
These sources say little of substance about integral speech; none provide an adequate exegesis of the category. One commentator does offer an explicit, if terse, explanation. He refers to integral speech as that which constitutes a "speech act" that furthers a crime. ${ }^{244}$ In other words, integral speech is that type of speech that is viewed less as speech and more as a "vehicle",245 that moves a criminal enterprise forward. ${ }^{246}$

Beyond that, the legal opinions and articles that apply integral speech are unhelpful in defining the category. Giboney v. Empire Storage $\mathcal{E}$ Ice Co., ${ }^{247}$

(D. Nev. Apr. 5, 2011); Garcia v. Newtown Twp., 819 F. Supp. 2d 416, 421 (E.D. Pa. 2011); United States v. Kim, 808 F. Supp. 2d 44, 56 (D.D.C. 2011); United States v. Larson, 807 F. Supp. 2d 142, 150, 163 (W.D.N.Y. 2011); United States v. Martinez, No. 10-60332-CR, 2011 WL 1099261, at *2 (S.D. Fla. Mar. 22, 2011); United States v. Robbins, 759 F. Supp. 2d 815, 817 n.3 (W.D. Va. 2011); Bass v. Hansen, No. 09-CV-1087, 2010 WL 5069690, at *8 (N.D. Ill. Dec. 7, 2010); Policastro v. Tenafly Bd. of Educ., 710 F. Supp. 2d 495, 504 (D.N.J. 2010).

243 See, e.g., J. Matthew Barnwell, Note, Taking a Bite Out of Speech Regulation: The Supreme Court Upholds First Amendment Protection for Depictions of Animal Cruelty in United States v. Stevens, 62 Mercer L. Rev. 1031, 1035, 1041 (2011); Andrew A. Beerworth, United States v. Stevens: A Proposal for Criminalizing Crush Videos Under Current Free Speech Doctrine, 35 VT. L. REv. 901, 908, 915, 920 (2011); Clay Calvert, Fighting Words in the Era of Texts, IMs and EMails: Can a Disparaged Doctrine Be Resuscitated to Punish Cyber-Bullies?, 21 DePAUl J. ART, TeCh. \& Intell. Prop. L. 1, 1 n.3 (2010); Clay Calvert \& Rebekah Rich, Low-Value Expression, Offensive Speech, and the Qualified First Amendment Right to Lie: From Crush Videos to Fabrications about Military Medals, 42 U. TOL. L. REV. 1, 11 (2010); Carol Federighi, Regulating Slate Mailers: Consumer Protection or First Amendment Infringement?, 14 HASTINGS Comm. \& ENT. L.J. 567, 575 n.51 (1992); Beatrice M. Hahn, The More Things Change, The More They Stay the Same: Schwarzenegger v. Entertainment Merchants Association, 6 DukE J. Const. L. \& Pub. Pol'y Sidebar 111, 114 (2011); Thomas B. McAffee, Overcoming Lochner in the Twenty-First Century: Taking Both Rights and Popular Sovereignty Seriously as We Seek to Secure Equal Citizenship and Promote the Public Good, 42 U. RICH. L. REV. 597, 619 (2008); Allen T. McGlynn, The Constitutional Ramifications of Calling a Police Officer an “Asshole," 16 S. ILL. U. L.J. 741, 743 (1992); Isaac Molnar, Comment, Resurrecting the Bad Tendency Test to Combat Instructional Speech: Militias Beware, 59 OHIO ST. L.J. 1333, 1348 n.112 (1998); Robert Rigg, The Not-So-Risky Business of High-End Escorts and the Internet in the 21st Century, 17 Rich. J.L. \& TECH. 3, 26 n.47 (2010); Nadine Strossen, United States v. Stevens: Restricting Two Major Rationales for Content-Based Speech Restrictions, 2010 CATO Sup. CT. Rev. 67, 80, 81 n.72, 85; Christina Wells, Regulating Offensiveness: Snyder v. Phelps, Emotion, and the First Amendment, 1 CALIF. L. REv. CirCUIT 71, 79 n.56 (2010).

244 Molnar, supra note 243, at 1348 n.112.

245 Powell's Books, Inc., 622 F.3d at 1212 n.15.

246 I refer to this type of speech as "operational" speech, or speech that effects a change in the position of people, goods, or services. In contrast, I refer to "aspirational" speech, which is speech that is intended to communicate or persuade. "Put all the small bills in a bag and give it to me," for example, is operational and is quasi-conduct because it directly results in a change in the position of the teller, the money, and the bag just as if the bank robber were to have put the money in the bag himself. "If you were to steal money from the bank, you'd be striking a blow at the unjust banking system" is aspirational. It is meant to communicate an idea and persuade opinion, not to effect a specific change in any position. I discuss aspirational and operational speech more in Part IV.

Giboney v. Empire Storage \& Ice Co., 336 U.S. 490, 498 (1949). 
which formally introduced the category in 1949, complicates the issue. United States $v$. Stevens, which gave the category contemporary life in 2010, is also unhelpful. ${ }^{248}$

\section{What is "Integral" Speech?}

In four cases, the category of integral speech has been prominent, if implicitly so. These cases are United States v. Stevens, ${ }^{249}$ New York v. Ferber, ${ }^{250}$ Ashcroft v. Free Speech Coalition, ${ }^{251}$ and Giboney v. Empire Storage $\mathcal{E}$ Ice Co. ${ }^{252}$ They leave a definition of integral speech undetermined.

In Stevens, the Supreme Court held that the First Amendment protected certain depictions of animal cruelty. ${ }^{253}$ Some have argued that Stevens breathed new life into the integral speech category. This is an overly optimistic view, because Stevens merely mentioned integral speech in a list of other categories of speech that enjoyed no First Amendment protection. ${ }^{254}$ It did so merely to illustrate that the First Amendment does not imply absolute protection for all speech. ${ }^{255}$

The Stevens Court refrained from expanding on its use of New York $v$. Ferber $^{256}$ to develop the integral speech category. In Ferber, the Court held that child pornography was an unprotected category of speech because " $[t]$ he market for child pornography was 'intrinsically related' to the underlying abuse, and was therefore 'an integral part of the production of such materials, an activity illegal throughout the Nation." ${ }^{257}$ The Ferber Court thus presented a consequentialist approach to understanding integral speech. If speech encourages or results in some other illegal conduct, then it is integral and unprotected. The Court's approach was fundamentally one of managing the effect in order to thwart the underlying illegal cause. ${ }^{258}$ Justice Alito, dissenting in Stevens, adopted Ferber's consequentialist theory. ${ }^{259}$

Id.

United States v. Stevens, 130 S. Ct. 1577, 1577 (2010).

New York v. Ferber, 458 U.S. 747 (1982).

Ashcroft v. Free Speech Coalition, 535 U.S. 234 (2002).

Giboney, 336 U.S. 490.

Stevens, 130 S. Ct. at 1582, 1592.

Id. at 1584 .

Id.

458 U.S. 747 (1982).

Stevens, 130 S. Ct. at 1586 (citing Ferber, 458 U.S. at 759).

Ferber, 458 U.S. at 761 n.13 ("The act of selling these materials is guaranteeing that there will be additional abuse of children." (quotation marks omitted)). 
Although the Ferber Court reached the correct normative result, it confused the category of integral speech. ${ }^{260}$

Integral speech is more correctly and elegantly a deontological category. ${ }^{261}$ To be "integral," speech must be a part of, and not a result of, criminal conduct. In Ashcroft v. Free Speech Coalition, the Court suggested Ferber's miscategorization, holding that virtual child pornography was generally protected. ${ }^{262}$ It so held because virtual child pornography did not result from actual child sexual abuse. ${ }^{263}$ The Court could have given deference to Congress' determination that virtual child pornography harms children in less direct ways. ${ }^{264}$ Instead, the Court adopted a deontological approach, implicitly rejecting the Ferber analysis and stating that the law prohibiting virtual child pornography prohibited speech that was attached to no crime. ${ }^{265}$

The Giboney opinion provides the first explicit acknowledgment of the integral speech category, to which Stevens and Ferber were later to refer. ${ }^{266}$ It does not invoke Ferber's consequentialist approach, preferring instead a deontological one. Even within that view, however, Giboney leaves us wanting a definition.

Giboney considered a labor dispute in which union members attempted to pressure a wholesale ice company to deal only with union ice peddlers. ${ }^{267}$ Union members engaged in conduct that was in violation of the state's antitrade restraint law. ${ }^{268}$ They also operated pickets that were peaceful and published only truthful information. ${ }^{269}$ The specific question was whether the state could enjoin union members from peaceful picketing "carried on as an essential and inseparable part of a course of conduct which is in

260 See Volokh, Speech as Conduct, supra note 9, at 1325 (discussing Ferber, Volokh noted that "not all speech that provides a motive for illegal conduct can be outlawed simply because it is 'an integral part of conduct in violation of a valid criminal statute'").

261 See United States v. Spock, 416 F.2d 165, 170 (1st Cir. 1969) (offering that by default, the court would "start with the assumption that the defendants were not to be prevented from vigorous criticism of the government's program merely because the natural consequences might be to interfere with it, or even to lead to unlawful action" (footnote omitted)).

262535 U.S. 234, 258 (2002).

263 Id. at 241.

264 Id. See Holder v. Humanitarian Law Project, 130 S. Ct. 2705, 2727 (2010) ("That evaluation of the facts by the Executive, like Congress's assessment, is entitled to deference.”); Turner Broad. Sys., Inc. v. FCC, 520 U.S. 180, 247 (1997) (O'Connor, J., dissenting) ("Congress' reasonable conclusions are entitled to deference ....").

265 Ashcroft, 535 U.S. at 250.

266 United States v. Stevens, 130 S. Ct. 1577, 1584 (2010); New York v. Ferber, 458 U.S. 747, 762 (1982).

267 Giboney v. Empire Storage \& Ice Co., 336 U.S. 490 (1949).

268 Id. at 491.

269 Id. at 493-94, 498. 
violation of the state law." ${ }^{270}$ In other words, if the union was engaged in conduct to illegally restrain trade, and engaged in speech that was "integral" to that conduct, could the speech be restricted?

The Court rejected the union position, stating that the picketing could not "be treated in isolation.,"271 "[T] he sole immediate object of the" picketing, "as well as the other activities of the [union] was to compel Empire to agree to stop selling ice to nonunion peddlers." ${ }^{272}$ These "other activities" included a "powerful transportation combination," patrolling, and a picket line that warned union members not to cross it. ${ }^{273}$ These activities plus the "publicizing" at the picketing "constituted a single and integrated course of conduct."

The Court's holding that integral speech is not protected is problematic for two reasons. First, the fact that the Court based its opinion on picketing that was peaceful and truthful begs the question: if it was peaceful and truthful, was it truly "integral" to criminal conduct? Second, lending First Amendment concern to this question, the Court indicated that the speech and the illegal conduct were separable. ${ }^{275}$ The Court could have held that the speech was protected, but not its associated illegal conduct. ${ }^{276}$

Giboney presents three possible definitions of integral speech. The category could include speech that is necessary to executing illegal conduct. ${ }^{277}$ It could include speech that facilitates (and may or may not be necessary to executing) the illegal conduct. ${ }^{278}$ The most likely reading of Giboney is that

$270 \quad$ Id. at $491-92$.

271 Id. at 498

$272 I d$.

273 Id.

274 Id.

$275 I d$. at 502 ("Nor can we say that the publication here should not have been restrained because of the possibility of separating the picketing conduct into illegal and legal parts.").

276 United States v. Spock, 416 F.2d 165, 173 (1st Cir. 1969) (describing the First Circuit's limited use of speech which, "responds to the legitimate apprehension ... that the evil must be separable from the good without inhibiting legitimate association in an orderly society"); Volokh, Speech as Conduct, supra note 9, at 1317 ("If the course of conduct includes illegality, the theory would go, then the speech part of the course of conduct would be just as illegal as the action that the speech brings about. This might fit the facts of Giboney-in which the speaker was trying to pressure the employer into acting illegally_and of some of the lower court cases that cite Giboney. But such a reading would be inconsistent with Brandenburg, and with the modern repudiation of cases such as Schenck and Debs." (footnote omitted)).

277 Cohen v. California, 403 U.S. 15, 27 (1971) (Blackmun, J., dissenting).

278 Ohralik v. Ohio State Bar Ass'n, 436 U.S. 447, 456 (1978) (quoting Giboney v. Empire Storage \& Ice Co., 336 U.S. 490, 502 (1949)) (" $[\mathrm{I}] \mathrm{t}$ has never been deemed an abridgement of freedom of speech or press to make a course of conduct illegal merely because the conduct was in part initiated, evidenced, or carried out by means of language, either spoken, written, or printed."); see Rice v. Paladin Enters., Inc., 128 F.3d 
speech that is merely related to the illegal conduct (and may or may not be facilitative or necessary) is not protected. ${ }^{279}$ If this is the case, then Giboney raises serious free speech issues that directly implicate the All-Purpose Speech Model, as we shall see.

\section{Greenawalt's Theory of Speech Acts}

Kent Greenawalt's extensive work on speech acts ${ }^{280}$ provides the best extant theoretical base from which to analyze speech's use in conspiracy cases. He sets forth a tripartite structure of speech, which includes "situation-altering utterances," "assertions of fact and value," and "weak imperatives." ${ }^{281}$ Although he groups weak imperatives and situation-altering utterances in the same category, and juxtaposes them with assertions of fact and value ${ }^{282}$ there are meaningful differences between the two.

\section{a. Greenawalt's Tripartite Structure of Speech}

Situation-altering utterances are words that "directly alter[] the social environment by 'doing' something rather than telling something or recommending something. Examples are words of agreement that commit people to action and threats that introduce a new danger into victims' lives." ${ }^{283}$ For Greenawalt, such words can be prohibited without a free

233, 243 (4th Cir. 1997) (relying on Giboney in allowing liability for publishing a book that described how to commit contract murders); see also United States v. Savoie, 594 F. Supp. 678, 682, 685-86 (D. La. 1984) (relying on Giboney in issuing an injunction against, among other things, the distribution of any document explaining how taxpayers could "avoid the payment of, or to obtain the refund of, federal income taxes ... based on the false proposition that wages, salaries or other forms of compensation for labor or services not specifically excluded from taxation under Title 26 of the United States Code are not taxable income").

279 See Missouri v. Nat'l Org. for Women, 620 F.2d 1301, 1324 n.15 (8th Cir. 1980) (Gibson, J., dissenting) (arguing, citing Giboney, that the National Organization for Women's advocacy of a boycott of Missouri businesses, aimed at getting Missouri to ratify the Equal Rights Amendment, might be constitutionally punishable as an antitrust law violation); Searle v. Johnson, 646 P.2d 682, 685 (Utah 1982) (holding, citing Giboney, that the state Humane Society's advocacy of a tourist boycott of a county, aimed at getting the county to improve its dog pound, could be constitutionally punishable as interference with prospective business advantage).

280 Kent Greenawalt, Fighting Words: Individuals, Communities, and Liberties of SpeEch (1995) [hereinafter Greenawalt, Fighting Words]; Greenawalt, Speech, Crime, AND The Uses Of LANGUAge, supra note 5; Kent Greenawalt, Free Speech in the United States and Canada, 55 LAW \& CONTEMP. Probs. 5, 12-13 (1992) [hereinafter Greenawalt, Free Speech]; Kent Greenawalt, Insults and Epithets: Are They Protected Speech?, 42 RUTGERS L. REV. 287, 290 (1990) [hereinafter Greenawalt, Insults].

281 GREENAWALt, Fighting WORDS supra note 280, at 7; GREENAWALT, supra note 5, at 43, 57.

282 GReEnawalt, SPEECH, CRIME, AND THe Uses OF LANGUAGE, supra note 5, at 57.

283 Greenawalt, Free Speech, supra note 280, at 13. 
speech problem. ${ }^{284}$ A situation-altering utterance could be saying "I do" to the priest who asks if you will marry the person next to you, ${ }^{285}$ or, in the conspiracy context, saying the same thing to the person who asks if you agree to rob a bank with him.

Weak imperatives are "requests and encouragements that do not sharply alter the listener's normative environment" because they do not create "new rights or new obligations or new consequences of [one's] behavior. Weak imperatives often indicate beliefs about values and facts and cannot always be disentangled from them." ${ }^{286}$ Weak imperatives are not commands. ${ }^{287}$ They are, for example, saying to your roommate, "Please shut the door,"288 or saying to your co-conspirator, "Kill him, Jack.",289

Greenawalt does not define assertions of fact and value, ${ }^{290}$ as the name of that category speaks for itself. He does, however, offer nuanced variations of these assertions. General assertions of fact include, "Physical objects have gravitational force," and "Your wife has a lover." ${ }^{291}$ Motivational assertions are made to achieve an end, and include telling your roommate, "The breeze from the window is making me cold." ${ }^{292}$

\section{b. Levels of Protection}

Greenawalt assigned different levels of First Amendment protection to his three categories of speech, based on how norm-altering they are. Assertions of fact and value deserve the highest level of speech protection, and situation-altering utterances deserve the lowest because they are "ways of doing things, not of asserting things," and so are subject to regulation just as is any noncommunicative behavior. ${ }^{293}$ Weak imperatives are given a level of protection between assertions of fact and value and situation-altering utterances, because they are norm-altering but not "sharply" so. ${ }^{294}$

\section{c. Speech on a Continuum}

Throughout his work, Greenawalt acknowledges that speech in the real world does not fall neatly into categories. Rather, it exists on a continuum.

Greenawalt, Insults, supra note 280, at 290.

Greenawalt, SPEech, CRIME, AND The Uses OF LANGUAGe, supra note 5, at 57.

Id.

GREENAWALT, Fighting WORDS, supra note 280, at 6.

Greenawalt, SPEECH, CRIME, AND THE Uses OF LANGUAGE, supra note 5, at 69. Kent Greenawalt, Speech, Crime \& The Uses of Language 69 (1989).

Id. at 43 .

$I d$.

$I d$. at 47 .

Id. at 58 .

Greenawalt, Insults, supra note 280, at 290. 
For example, weak imperatives in the form of "requests and encouragements," imply assertions of fact and value. ${ }^{295}$ Greenawalt also groups weak imperatives with situation-altering utterances, ${ }^{296}$ thus implying their overlap. To complete the circle, Volokh has noted that assertions of fact and value can be situation-altering because they may alter a hearer's normative environment. ${ }^{297}$

\section{B. Problems With Greenawalt's Tripartite Structure}

Throughout his writing, Greenawalt implies that his structure is not perfect, and perhaps for that reason attempts to set forth not an absolutely true structure, but one that serves a purpose. ${ }^{298}$ The question, then, is whether his structure is useful for analyzing the use of speech in conspiracy cases. ${ }^{299}$ A better system is possible.

Four criticisms of Greenawalt's structure in the context of conspiracy charges present themselves. They begin from Greenawalt's acknowledgement that all three of his categories overlap. In the conspiracy context, they go far beyond overlapping; they each become as useful as the others, and in the same ways. This is the blunderbuss problem of speech admissibility I refer to above. For example, an assertion of fact and value, "The bank is open from 9 a.m. to 5 p.m.," can be used simultaneously to infer an agreement, as an overt act, and to prove mens rea. A weak imperative, "[w]e could really use some ammunition," and a situationaltering utterance, "I'll steal the getaway car if you buy the ski masks," can both perform the exact same functions.

So the first criticism is that in the conspiracy context, Greenawalt's three categories are not meaningfully different. This is so in part because Greenawalt was concerned with speech as crime, and not with speech as evidence thereof. Indeed, in expressing his concern that ambiguous speech or "weak agreements" might wrongly be used to prove a conspiratorial

295 Greenawalt, SPEECH, CRime, AND The USES Of LANGUAGE, supra note 5, at 69.

296 See id. at 57 ("The terrain divides itself into two large categories: what I call situationaltering utterances, on the one hand, and requests and encouragements, or what I call weak imperatives, on the other. With some strain, all my examples might be pressed into the 'situation-altering' category, but to do so would be to obscure how requests and pure encouragements differ critically from other uses I discuss.").

297 See Volokh, Speech as Conduct, supra note 9, at 1328 (discussing, for example, how a newspaper editorial could affect an individual's behavior not necessarily because of the facts contained in the editorial but because of their assertive tone).

298 Greenawalt, SPeEch, Crime, ANd The Uses of Language, supra note 5, at 40.

299 See, e.g., William James, Pragmatism's Conception of Truth, in THE NATURE OF TruTH: Classic And Contemporary Perspectives 211, 213, 217 (Michael P. Lynch ed., 2001). 
agreement, ${ }^{300}$ he remained focused on the speech-as-crime side of the AllPurpose Speech Model. He therefore noted that conspiratorial agreements have never been supposed to raise free speech problems, ${ }^{301}$ and, in the end, "freedom to say what one feels and believes and hopes to do does not constitute freedom from use of one's statements as evidence." ${ }^{302}$ To prevent the use of speech as evidence would threaten public safety, and so "we can simply regard the First Amendment as not ordinarily precluding evidentiary use of what people say." ${ }^{303}$

The second criticism arises from Greenawalt's acknowledgement that ambiguous speech, weak agreements, and, I would add, the fact that agreements can be inferred, create outcome reliability problems. ${ }^{304}$ This is true as far as he takes it, which is to the use of such speech as the agreement itself. But this is a problem for the use of speech as evidence as well. Greenawalt's focus on speech-as-crime led him to conclude that "[e]ven constitutionally protected communications can help establish intent." ${ }^{, 05}$ His examples are too easy: "I will kill Claude," he says, should be used to prove that Alice intended to shoot Claude, as should Alice's statement, "I hate Claude and would like to see him dead., ${ }^{306}$

Greenawalt's conclusion is less certain in light of tougher examples. What if Alice had said the following: "[k]illing is sometimes justified by my religion, when it is to stop evil people"; "[i]f our leaders can murder people in drone attacks, then I can kill too"; or "my faith has been shaken over the last year, so that even killing does not seem immoral anymore." Consider, furthermore, that Claude was not actually shot, and that Alice is charged only with conspiracy to kill Claude. In that case, the use of Alice's apparently protected speech is problematic.

The third criticism is that Greenawalt's structure might protect too much speech. He says that a speaker's motives and objective in speaking are irrelevant to determining its protection. ${ }^{307}$ This statement is valid if the question is only whether a particular speech act should be a crime or not: situation-altering utterances should not be protected, whatever the speaker's motive, because they are like non-communicative behavior, and assertions of

Greenawalt, Speech, Crime, And The Uses of Language, supra note 5, at 81 (hypothesizing that a group of young men who agree not to submit to the draft do not necessarily depend on each other's involvement to commit the crime, but that conspiracy could be proven nonetheless).

Id. at 245 .

Id.

$I d$. at 47 . 
fact and value should be protected, whatever the speaker's motive, because even despite a bad motive, such assertions are located at the First Amendment's core. ${ }^{308}$

When conspiracy is the alleged crime, a speaker's intent matters greatly to infer agreement, provide an overt act, and establish mens rea. If I tell my friend, "[t]here are three guards at the bank, lightly armed," this can be used to infer an agreement and can certainly be considered an overt act because my intention is that my bank-robbing co-conspirator be informed about the bank's security apparatus. ${ }^{309}$ One observer has argued that " $[\mathrm{t}] \mathrm{o}$ prevent the use of conspiracy law to convict individuals on the basis of their ideas, courts should bar the use of constitutionally protected public expression as evidence either of an overt act or of an individual's specific intent. $^{, 310}$ While this would go far in addressing the problems associated with the All-Purpose Speech Model, it would also throw the relevant baby out with the problematic bathwater.

The fourth criticism emerges from Greenawalt's assertion that "weak agreements" can be taken as encouragements and therefore protected. ${ }^{311}$ This may be the normatively right result, but in conspiracy law, encouragements are clearly admissible as overt acts. ${ }^{312}$ Greenawalt's structure does not, and cannot, address this important fact.

\section{Distilling Greenawalt's Structure}

From Greenawalt's tripartite structure emerges a more useful two-part structure, which includes what I call "operational" and "aspirational" speech. Operational speech is that which effects a change in the position of people, goods, or services. ${ }^{313}$ Aspirational speech is that which is intended to communicate or persuade. ${ }^{314}$ These categories better reflect the interests

\footnotetext{
$308 I d$. at 43 (explaining the assertions of fact and value should be protected because "[c]laims about general facts are critical for people's understanding of the world they inhabit, for their choices about how to live, and for their decisions on public issues. The truth-discovery justification applies strongly to general factual statements, and suppression of such statements would undermine independence of judgment and personal development").

309 See United States v. Khamsomphou, 111 F. App’x 937, 939 (9th Cir. 2004).

310 Note, Conspiracy and the First Amendment, supra note 1, at 894.

311 Greenawalt, SPEeCH, CRIME, AND THE USES OF LANGUAGE, supra note 5, at 240.

312 United States v. Fernandez, 559 F.3d 303, 328 (5th Cir. 2009).

313 This is akin to Thomas I. Emerson's "action" speech. Emerson, supra note 11, at 917 ("Expression often takes place in a context of action, or is closely linked with it, or is equivalent in its impact.").

314 This concept is related to Thomas I. Emerson's notion of expression. EMERSON, supra note 4 , at 8 .
} 
involved in the confluence of speech and conspiracy law ${ }^{315}$ : on one hand, we want to protect people's right to express themselves freely, through aspirational speech, but we also want to allow operational speech to be used against a conspiracy defendant.

This two-part structure is a reformulation of Greenawalt's tripartite structure. Recall that he grouped situation-altering utterances and weak imperatives in the same category because they are both norm-altering. These two types of speech track well with operational speech; both are used to effect a real change in the world. Similarly, both assertions of fact and value and aspirational speech are meant to communicate ideas or facts often for core First Amendment purposes.

The two-part structure is more useful than Greenawalt's structure in the conspiracy context because the two-part structure labels speech in ways that are more relevant to conspiracy law. ${ }^{316}$ Greenawalt wrote that there is no First Amendment problem to admitting speech when "new commitments have unambiguously been undertaken, ${ }^{317}$ and to using speech as an overt act when "it reveals on its face a criminal intent or is indisputably a step in a criminal plan." ${ }^{318}$ These statements point to operational speech, and would, as far as they go, leave aspirational speech protected. Furthermore, they suggest that the important division is between aspirational and operational speech. To illustrate, statements of fact and value could be operational ("The guards change shifts at 3 P.M."), as could weak imperatives ("We need some guns"). ${ }^{319}$ Both, in turn, could be clearly situation-altering. ${ }^{320}$ A robber could point a gun at someone and say, "give me your money or I will pull the trigger." The robber could achieve the same result by cornering the victim, holding a gun to his side, away from the victim, and say, "I'm out of work, I need money, and this economic downturn is making me really desperate. I'd be grateful if you could help a guy out." The victim will certainly take

315 Indeed, Thomas I. Emerson suggested as much. Emerson, supra note 11, at 955 ("[T] he essence of a system of freedom of expression lies in the distinction between expression and action.”). Eugene Volokh also may have implied this two-part structure. See Volokh, Crime-Facilitating Speech, supra note 10, at 1217; Volokh, Speech as Conduct, supra note 9, at 1284 ("Expression can generally be regulated to prevent harms that flow from its noncommunicative elements (noise, traffic obstruction, and the like), but not harms that flow from what the expression expresses." (footnote omitted)).

316 This view reflects Thomas I. Emerson's two-part typology of group association, dividing it, as he did, between "expression" and "action." Emerson, supra note 3, at 24-25.

317 Greenawalt, SPEeCH, Crime, AND The Uses of LANGUAGE, supra note 5, at 240.

318 Id. at 246

319 See Volokh, Speech as Conduct, supra note 9, at 1285 ("[T] $[$ here are many examples of speech that alters people's felt moral obligations, but that nonetheless seems to be pure speech rather than conduct."). 
this as a situation-altering utterance, but it contains only assertions of fact and a weak imperative.

The Court in Dennis v. United States and Yates v. United States invoked, if obliquely, the two-part structure. In both cases, the government brought conspiracy charges based on aspirational speech. In Dennis, the defendants "agreed to assemble and to talk and publish certain ideas at a later date.",21 They did not organize the communist party, but agreed to organize it, and they did not teach or advocate the overthrow of the government, but merely agreed to do so. ${ }^{322}$ In Yates, the Court reaffirmed the notion that aspirational speech in the form of organization and advocacy was subject to Smith Act prohibitions. ${ }^{323}$ In reversing the defendants' convictions because they did not engage in such speech, the Court acknowledged "that distinctions between advocacy or teaching of abstract doctrines, with evil intent, and that which is directed to stirring people to action, are often subtle and difficult to grasp.” ${ }^{324}$ For the Court, then, the difference was whether the defendants merely wanted to communicate an idea, or whether they wanted, through their words, to effect a change in others that was intended to lead to illegal conduct.

\section{Combining Integral Speech and the Aspirational-Operational Structure}

Integral speech and the aspirational-operational structure both provide important contributions ${ }^{325}$ and can be combined in a revealing way. In asking whether certain speech is necessary, facilitative, or merely related to an alleged conspiracy, we are asking the question posed by the actus reus requirement: did speech required to prove a crime occur? In asking whether a certain speech act is aspirational or operational, we are asking the mens rea question: what did the speaker intend? Although certainly not a perfect analogy, this does suggest that both structures bring something important to the question of conspiracy's threat to free speech.

From integral speech and the aspirational-operational structure, six categories of speech emerge: aspirational speech that is necessary, facilitative, or related to criminal conduct, and operational speech that is necessary, facilitative, or related to criminal conduct.

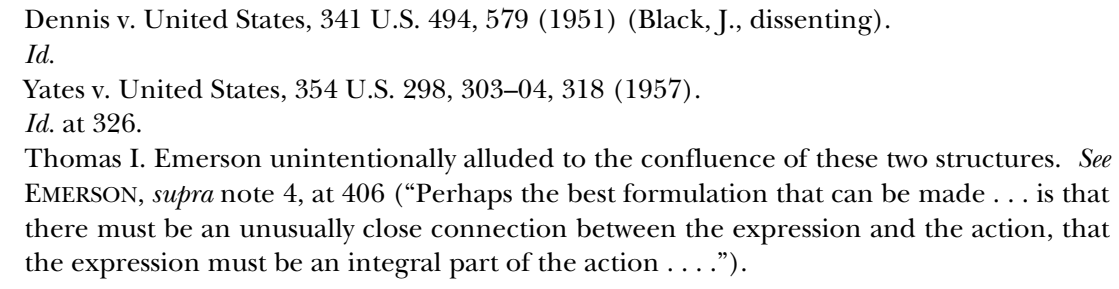


Aspirational-necessary speech does not actually exist in the real world: if speech is necessary, it is by definition operational. Similarly, operationalrelated speech also does not exist: if the speech is operational, it is by definition either necessary or facilitative. We need not, therefore, consider these categories.

What remains is operational-necessary, operational-facilitative, aspirational-facilitative, and aspirational-related speech. Normatively and based on principles of free speech, we start from the initial position that each of these, in the order presented, becomes more protected and usually less relevant to proving a conspiracy. Operational-necessary and operational-facilitative speech tend to pose fewer free speech concerns ${ }^{326}$ because they are likely to be relevant and probative ${ }^{327}$ and unlikely to include high-value speech such as political or artistic expression. ${ }^{328}$ In turn, aspirational-facilitative and aspirational-related speech tend to be highvalue. ${ }^{329}$ In addition to being "core" First Amendment speech, this speech is often not necessary to completion of a crime, and may not indicate the requisite mens rea. ${ }^{330}$ This speech is often ambiguous because it either might carry innocent meaning ("the banking system is unjust") or it might be mere bluster that is not probative of a crime ("If they ever make me carry a rifle, the first man I want to get in my sights is" the president ${ }^{331}$ ).

The four types of speech discussed and the initial levels of protection and relevance that inhere in each track the speech concerns that conspiracy law raises. This structure is, therefore, helpful in illustrating the free speech concerns inherent in the All-Purpose Speech Model.

\section{OF CONSPIRACIES AND ThreATS to PRINCIPLES OF FreE SPEECH}

The history of the First Amendment is the history of establishing levels of speech protection based upon principles of free speech, including the

Greenawalt, SPEech, CRIME, AND The Uses Of LANGUAGe, supra note 5, at 240, 246.

See Note, Conspiracy and the First Amendment, supra note 1, at 894 (arguing that "[w] hen the non-expressive objective of a group has been accomplished or attempted by means of both expression and action not incidental to that expression... dismissal of the indictment" is not required).

William Van Alstyne, A Graphic Review of the Free Speech Clause, 70 CALIF. L. Rev. 107, 141 (1982). Of course, this Article challenges this common sense position, arguing that even high-value political, religious, or artistic speech can be probative or at least appear to be probative.

See Greenawalt, SPeEch, Crime, And The Uses of Language, supra note 5, at 58 ("My essential claim ... is that [situation-altering] utterances.... are outside the scope of a principle of free speech.").

Huq, supra note 9 .

Watts v. United States, 394 U.S. 705, 706 (1969) (holding that petitioner's similar statement in regards to President Johnson were crude political hyperbole and not a knowing and willful threat). 
search for truth ${ }^{332}$ serving the democratic process and self-government, ${ }^{333}$ enabling the marketplace of ideas, ${ }^{334}$ tolerance, ${ }^{335}$ and ensuring individual autonomy and dignity. ${ }^{336}$ Based on these principles, courts and scholars have placed different types of speech at different levels of protection.

Scholars generally conceive of three levels of protection. ${ }^{337}$ The first division is between speech that is protected, though not absolutely, by the First Amendment, and speech that is not constitutionally protected. ${ }^{338}$ Speech that is not protected by the First Amendment can be called "novalue" speech. Speech that is protected by the First Amendment is subdivided into high-value ${ }^{339}$ (or "core" ${ }^{\text {"30 }}$ ) and regulable" (or "lowvalue ${ }^{,{ }^{342}}$ ) speech. High-value speech includes political, ${ }^{343}$ public issue, ${ }^{344}$ religious, ${ }^{345}$ and artistic speech; ${ }^{346}$ regulable speech is, for example, commercial speech, ${ }^{347}$ and no-value speech includes things like obscenity ${ }^{348}$

Greenawalt, SpeEch, CRIME, AND The Uses Of Language, supra note 5, at 16.

Garrison v. Louisiana, 379 U.S. 64, 75 (1964).

Abrams v. United States, 250 U.S. 616, 630 (1919) (Holmes, J., dissenting).

LeE C. Bollinger, The Tolerant Society: Freedom of SPEech and EXTREmist SPEech IN AMERICA 4 (1986).

RODNEy A. SMOLLa, Free SPEECH IN AN OPEN SOCiety 9 (1992).

See Richard A. Posner, The Speech Market and the Legacy of Schenck, in EtERnALly VigilanT: FREE SPEECH IN THE MODERN ERA, supra note 2, at 120, 132.

See Chaplinsky v. New Hampshire, 315 U.S. 568, 571-72 (1942) ("There are certain welldefined and narrowly limited classes of speech, the prevention and punishment of which have never been thought to raise any Constitutional problem." (footnote omitted)); R.A.V. v. City of St. Paul, 505 U.S. 377, 382-83 (1992) ("[O]ur society . . has permitted restrictions upon the content of speech in a few limited areas, which are 'of such slight social value as a step to truth that any benefit that may be derived from them is clearly outweighed by the social interest in order and morality." (quoting Chaplinsky, 315 U.S. at 572)); see also Frohwerk v. United States, 249 U.S. 204, 206 (1919) ("[W]e have decided ... that a person may be convicted of a conspiracy to obstruct recruiting by words of persuasion." (emphasis added)).

West, supra note 38, at 1049-50.

R.A.V., 505 U.S. at 422 (Stevens, J., concurring).

See, e.g., Daniel Winik, Note, Citizens Informed: Broader Disclosure and Disclaimer for Corporate Electoral Advocacy in the Wake of Citizens United, 120 YALE L.J. 622, 654 (2010); Eugene Volokh, The Trouble with "Public Discourse" as a Limitation on Free Speech Rights, 97 VA. L. REV. 567, 572 (2011).

Cass R. Sunstein, Pornography and the First Amendment, 1986 DuKE L.J. 589, 602-04 (1986); Christopher S. Yoo, Technologies of Control and the Future of the First Amendment, 53 WM. \& MARY L. REV. 747, 748 (2011).

Arizona Free Enter. Club's Freedom Club PAC v. Bennett, 131 S. Ct. 2806, 2816-17 (2011).

Snyder v. Phelps, 131 S. Ct. 1207, 1215 (2011).

Douglas Laycock, High-Value Speech and the Basic Educational Mission of a Public School: Some Preliminary Thoughts, 12 LEWIS \& CLARK L. REV. 111, 113 (2008).

Paul Dyson, Frying Up the First Amendment: A Look at the Effects of Frye v. Kansas City on Your Freedom of Speech, 48 S. TEx. L. REv. 283, 297 (2006).

Sorrell v. IMS Health Inc., 131 S. Ct. 2653, 2672 (2011).

Miller v. California, 413 U.S. 15, 23-24 (1973). 
and solicitation to murder. ${ }^{349}$ In general, the poles are occupied by political speech as the most protected and criminal speech as the least protected. ${ }^{350}$

In addition to providing a structure for First Amendment analyses, these levels of protection tell us a lot about what speech is valuable in light of free speech principles. They also highlight the threats that conspiracy law poses to these principles. Consider where in this system the parts of conspiracy law reside. The criminal conspiracy itself is not a speech act, but a criminal combination of people, and so it is non-speech. Its major element, agreement, is a speech act, but is so essential to the crime of conspiracy that it can be considered to be prohibited and unprotected. When an overt act is required and it consists of speech, that element is also prohibited and unprotected. If the underlying conspiracy indictment is normatively acceptable, then there is little concern with free speech at this point.

The problem presented by the All-Purpose Speech Model arises when the evidence used to infer an agreement and to provide the overt act is considered. This evidence, which as I have argued becomes essentially the crime itself, resides at all levels of protection. Al-Hussayen's and Mehanna's speech consisted often of trenchant criticism of the United States' wars in Iraq and Afghanistan-certainly a political and public issue of great importance. Their speech also couched this criticism in religious talk of jihad, which often had innocent and directly religious meaning. This speech was high-value, just as was speech engaged in by communists in the 1950s and hip-hop fans more recently.

Integral speech further illustrates this problem. The Court has held this category to be unprotected, ${ }^{351}$ but has failed to recognize its vagaries. This poses serious questions for free speech. If integral speech means speech that is necessary to achieve a criminal aim, then the Court was correct in labeling it unprotected. If integral speech includes facilitative and related speech, then labeling all integral speech unprotected is conceptually problematic. Related speech presents the greatest concern. In the Mehanna case, the defendant spoke in favor of jihad. Such speech was religious, political, and concerned a public issue, and so in isolation should have been treated as high-value speech. If Mehanna had actually conspired to provide

349 See Julia K. Wood, Note, Truth, Lies, and Stolen Valor: A Case for Protecting False Statements of Fact Under the First Amendment, 61 Duke L.J. 469, 474 (2011) (discussing "restrictions on expression that have been accepted as essential to the orderly function of society, such as ... the solicitation of murder").

350 Van Alstyne, supra note 328, at 141.

351 See, e.g., United States v. Stevens, 130 S. Ct. 1577, 1580 (2010) (holding that "speech integral to criminal conduct" is unprotected); Giboney v. Empire Storage \& Ice Co., 336 U.S. 490, (1949) ("The constitutional freedom of speech and press does not immunize speech or writing used as an integral part of conduct in violation of a valid criminal statute."). 
material support to al Qaeda (a contention I reject, the guilty verdict notwithstanding), his pro-jihad talk was likely only related to this conspiracy. For free speech purposes, there is little justification for equating this speech with orthodox necessary speech: Mehanna's jihad talk was utterly unlike, for example, speech engaged in by someone who solicits a spouse's murder.

The operational-aspirational distinction creates another conceptual difficulty. There is, to be sure, an important difference between the two types of speech, ${ }^{352}$ but it is not obvious that the two types of speech can be distinguished effectively. ${ }^{353}$ For example, assuming arguendo that Mehanna actually wanted to encourage others to fight jihad, he also clearly wanted to register his opposition to the United States' military presence in the Middle East. It is unclear whether this speech should be treated as operational, aspirational, or both. If it is at least in part aspirational, then its use against Mehanna puts serious pressure on core First Amendment speech.

Principles of free speech may not be threatened by placing the agreement and overt act at the level of prohibited unprotected speech. When, however, evidence in support of these elements comes from all levels of protection, and when the evidence emerges as the sole manifestation of the crime of conspiracy itself, these levels are obliterated. In the context of conspiracy, then, there is no high-value speech-all speech, including political, religious, and artistic, becomes admissible, and becomes, in effect, the crime itself.

The logical response to this concern is that criminal conspiracies are dangerous and even high-value or aspirational speech is relevant to proving them. In run of the mill conspiracy cases, such as those involving drug trafficking, child pornography, or insider trading, prosecutorial forbearance and judicial gatekeeping keep expansive and speech-threatening conspiracy charges at bay. The conceptual uncertainties inherent in the Conspiracy Specific Speech Typology are not such a problem in these cases, because the federal government usually charges only easily provable cases of clear criminality. In heady times when communists, drug runners, and Islamist terrorists appear to threaten the country, the government openly engages an

352 See Emerson, supra note 4, at 21 ("[That] maintenance of a system of freedom of expression requires recognition of the distinction between those forms of conduct which should be classified as 'expression' and those which should be classified as 'action' ....").

353 ALEXANDER, supra note 27, at 79 ("I believe that none of these attempts to sever incitement and solicitation from advocacy succeeds. Incitement and solicitation are no more or less 'acts' than any other speech that may cause a harmful response." (footnote omitted)); C. EDWIN BAKER, Human LiberTy AND FrEedom OF SPEECH 71 (1989) ("If the distinction is between 'expressing' and 'doing,' most conduct falls into both categories. Most consciously undertaken actions are at least self-expressive; and many ... can be primarily intended to communicate something to others."). 
expansive prevention paradigm. ${ }^{354}$ This requires prosecutors to indict those who appear to pose such threats at the earliest possible moment. ${ }^{355}$ While perceived crises such as the Wars on Communism, Drugs, and Terrorism may give this approach some justification, they also give currency to free speech problems associated with the All-Purpose Speech Model.

\section{CONCLUSION}

"That darling of the modern prosecutor's nursery."

- Judge Learned Hand, on conspiracy law. ${ }^{356}$

"[The people's] darling privilege."

- Congressman Harrison Gray Otis, on freedom of the press. ${ }^{357}$

This Article is about the inseparable relationship between conspiracy law and speech rights, and the conflict between them. It is also about coming to terms with the implications of a relatively new, but incredibly expansive, ${ }^{358}$ system of free speech. What this system entails remains to be seen.

The All-Purpose Speech Model reveals the threats that conspiracy law poses to free speech. When speech located at all levels of First Amendment protection is used as the crime of conspiracy and as evidence thereof, those levels of protection are obliterated, and the supposedly distinct elements of conspiracy are recognized as illusory. As these conceptual walls fall, the threat to free speech increases. The cases of Sami Omar Al-Hussayen and Tarek Mehanna, and the use of speech related to jihad, communism, and hip-hop, illustrate this threat.

If this Article has done its job, it should be clear at this point that conspiracy law puts serious pressure on the principles of free speech. It leaves for future work the inquiry whether conspiracy law may violate the First Amendment itself. That subject is an important one, and deserves more attention than can be paid in these pages. I want, however, to suggest that the future of speech rights lays, in part, in constitutional challenges to conspiracy law.

354 Gonzales, supra note 151.

355 See Pollack, supra note 1, at 339 ("It is natural ... that the crime of conspiracy should have its origin in a time of social unrest, revolutionary activity, and general insecurity of the powers in control.").

356 Harrison v. United States, 7 F.2d 259, 263 (2d Cir. 1925).

357 Michael Kent Curtis, Free Speech, “The People’s Darling Privilege”: Struggles for FREEDOM OF EXPRESSION IN AMERICAN HISTORY 4 (2000).

358 Bollinger, supra note 335, at 3; Frederick Schauer, First Amendment Opportunism, in Eternally Vigilant: Free SPEech in the Modern ERA, supra note 2, at 175, 175-76. 
The threshold question is what level of protection should be given to conspiratorial speech. ${ }^{359}$ Most scholars assume that the answer is "none at all., ${ }^{360}$ There is, however, a substantial countervailing opinion. Kent Greenawalt has suggested that some, but not all, criminal speech should fall under the First Amendment's aegis, and be subject to the "clear and present danger" test and its Brandenburg revision. ${ }^{361}$ Lee Bollinger has also acknowledged that ordinary criminal behavior can also be political expression, and so raises difficult First Amendment questions. ${ }^{362}$ The Supreme Court in Dennis would seemingly foreclose many conspiracy prosecutions on First Amendment grounds with its rule that "where an offense is specified by a statute in nonspeech or nonpress terms, a conviction relying upon speech or press as evidence of violation may be sustained only when the speech or publication created a 'clear and present danger' of attempting or accomplishing the prohibited crime." ${ }^{, 63}$

Assuming that conspiracy's speech is placed under the aegis of the First Amendment, and thus subject to the Brandenburg test, ${ }^{364}$ the next question is whether this speech is intended and is likely to produce "imminent lawless action." ${ }^{365}$ Here, too, there are diverging viewpoints. The majority opinion is that the conspiracy itself is dangerous, ${ }^{366}$ and so any speech used to produce it fails the Brandenburg test ab initio and is unprotected.

There are two responses to this. First, the Constitution requires that speech rights be maximized wherever possible. ${ }^{367}$ Speech ought to be

359 See BAKER, supra note 353, at 161 (arguing that "[n]ot all laws that have the effect of restricting some speech or assembly amount to an abridgement" under the First Amendment).

360 Kent Greenawalt, "Clear and Present Danger" and Criminal Speech, in ETERnalLy Vigilant: FREE SPEECH IN THE MODERN ERA, supra note 2, at 97, 111 ("It is far preferable to say that orders deserve no protection whatever." (footnote omitted)); Van Alstyne, supra note 328, at 141; see also Chaplinsky v. New Hampshire, 315 U.S. 568, 571-72 (1942).

361 Kent Greenawalt, "Clear and Present Danger" and Criminal Speech, in ETERNALly VigiLanT: FREE SPEECH IN THE MODERN ERA, supra note 2, at 97, 113-19.

362 Lee C. Bollinger \& Geoffrey R. Stone, Dialogue to EtERnally Vigilant: Free SPEech in THE MODERN ERA, supra note 2, at 1, 21.

363 Dennis v. United States, 341 U.S. 494, 505 (1951).

364 See AleXANDER, supra note 27, at 76 ("Brandenburg $v$. Ohio sets forth a test for when advocacy of harmful acts can be punished without violation of the First Amendment." (footnote omitted)).

365 Brandenburg v. Ohio, 395 U.S. 444, 447 (1969).

366 Dennis, 341 U.S. at 511; Yates v. United States, 354 U.S. 298, 324 (1959); Larry Alexander \& Kimberly Kessler Ferzan, Danger: The Ethics of Preemptive Action, 9 OHIO ST. J. CRIM. L. (forthcoming 2012) (manuscript at 8) (on file with author), available at http://ssrn.com/abstract=192434.

367 Abrams v. United States, 250 U.S. 616, 630 (1919) (Holmes, J., dissenting) ("[W]e should be eternally vigilant against attempts to check the expression of opinions that we loathe and believe to be fraught with death, unless they so imminently threaten immediate 
restricted only where the result of protecting it would be a "serious evil",368 that "rises far above public inconvenience, annoyance, or unrest.", Indeed, criminal statutes that infringe upon free speech must be particularly scrutinized: "those [laws] that make unlawful a substantial amount of constitutionally protected conduct may be held facially invalid even if they also have legitimate application. ${ }^{, 370}$

Second, the danger that conspiracy law supposedly poses in a First Amendment analysis should not be self-defining. ${ }^{371}$ Although some scholars have provided excellent defenses of conspiracy law, ${ }^{372}$ they have not made convincing arguments that all conspiracies are so dangerous that their speech should fail the Brandenburg test. ${ }^{373}$ Conspiracy qua conspiracy is not necessarily dangerous. ${ }^{374}$ While this is certainly a normative call for prosecutorial restraint, ${ }^{375}$ it also raises the constitutional issue: if a prohibition on speech does not address an actual danger, then it is more likely to violate the First Amendment.

interference with the lawful and pressing purposes of the law that an immediate check is required to save the country.").

371 Nor should speech alleged to be related to a criminal conspiracy be self-defined as unprotected. Much of this speech is part of the public discourse on core First Amendment issues, as in the Al-Hussayen and Mehanna cases. Ipse dixit declarations that such speech is unprotected may be arbitrary and unresponsive to principles of free speech. ALEXANDER, supra note 27, at 140.

372 Katyal, supra note 1.

373 Relatedly, Larry Alexander has expressed doubts that unprotected speech such as incitement and solicitation can be effectively separated from protected advocacy. ALEXANDER, supra note 27, at 79.

374 Larry Alexander and Kimberly Kessler Ferzan argue convincingly that dangerousness, linked to action, must determine whether blame and punishment are warranted. LARRY Alexander \& Kimberly Kessler Ferzan, Crime \& Culpability: A Theory of Criminal LAW 198-99 (2009). They question whether intentions are culpable acts in themselves, and base the answer on whether the intention alters the world in some way that is material to criminal law's concerns, and whether the formation of the intention is itself intentional. $I d$. at 200. In his seminal treatise on conspiracy law, Robert Samuel Wright similarly observed that the criminality of a conspiratorial agreement should depend upon the potential harm of the intended result. If the agreement is unlikely to result in the intended substantive crime, then it should not be punished. WRIGHT, supra note 12, at 35-36. Echoing Wright's analysis, the Dennis Court invoked Learned Hand's cause-andeffect calculation: "In each case [courts] must ask whether the gravity of the 'evil,' discounted by its improbability, justifies such invasion of free speech as is necessary to avoid the danger." Dennis v. United States, 341 U.S. 494, 510 (1951) (quotation marks omitted). People form conspiracies intentionally, but they can be seen as mere intentions to do something, often with no real threat of a resulting danger. If this is the case, then conspiracies should not be punished. The response, of course, is that the conspiracy itself is the action and the danger that can be punished. Id. at 576-77 (Jackson, J., concurring).

375 WRIGHT, supra note 12 , at $83-84$. 
Finally, the All-Purpose Speech Model proposes that conspiracy law produces the same threats to free speech that the Brandenburg Court did not countenance. The Court was confronted with "a statute which, by its own words and as applied, purport[ed] to punish mere advocacy and to forbid, on pain of criminal punishment, assembly with others merely to advocate the described type of action." ${ }^{376}$ In light of the All-Purpose Speech Model, conspiracy law punishes the very same advocacy and forbids the very same assembly. This threatens free speech and may, in fact, violate the First Amendment.

376 Brandenburg v. Ohio, 395 U.S. 444, 449 (1969). 